\title{
UNA VILLA DE SEÑORIO. OLIVA EN EL SIGLO XVIII (*)
}

\author{
Antonio MESTRE \\ Universidad Valencia
}

Al hablar del siglo XVIII español, los historiadores centramos nuestro interés en los aspectos demográficos, económicos, políticos o culturales-religiosos, en su vertiente más amplia y generalizadora. Así hablamos del ritmo de crecimiento secular en la economía o en la demografía, del centralismo borbónico, de la ilustración o de la religiosidad popular. Pero, excepto en el caso de la demografía -y en menor escala, de la economía- apenas fijamos la atención en la forma concreta como se desarrollaba la vida de cada día. Mi intento consiste en acercarme al modo de vida en un pueblo medio y observar cómo afrontaban sus vecinos las necesidades materiales y de convivencia. Oliva, pueblo de señorío, del antiguo Reino de Valencia y situado entre las actuales provincias de Valencia y Alicante, será el objeto de mi atención.

(*) Dado que las citas pueden resolverse con claridad sin recurrir a notas marginales, indico las fuentes y bibliografía básicas. Desgraciadamente carezco del Archivo Municipal, quemado en 1936. En cambio, he podido contar con los archivos de las dos parroquias (Santa María y San Roque). También encontré el documento sobre el sistema de contribución de los diezmos en el Archivo de la Catedral de Valencia. Pero la base fundamental es el inmenso acerbo de cartas de olivenses del siglo XVIII conservadas en los diferentes archivos de los Mayans: Archivo Municipal de Valencia (Serrano Morales), Colegio de Corpus Christi (Patriarca), Fondo Familia Alegre. Son cartas de todos los grupos sociales: los hermanos Mayans, alcaldes y regidores, clérigos, médicos, abogados, agricultores, mujeres del pueblo... Entre la bibliografía relativa a Oliva, señalo, VV.AA., Iniciación a la historia de Oliva, Valencia 1977: F. PONS FUSTER, Aspectos económico-sociales del condado de Oliva (ss. XVI-XVII), Valencia 1978;

F.PONS MONCHO, Trapig, Gandía 1979; J.Ma. DOMINGUEZ y F. PONS MONCHO, Sant Roc d'Oliva. Apuntes históricos, Oliva 1989; F. COTS, Estudio histórico-artístico del templo de Santa María la Mayor de Oliva, Oliva 1989. Respecto a la administración local, en cuyo marco se desarrolla el municipio, pueden verse, J. GUILLAMON, Las reformas de la administración local durante el reinado de Carlos III, Madrid 1980; D. BERNABE, "La administración local", en Historia de la Provincia de Alicante, vol.IV, Edad Moderna, Murcia 1985; y una breve, pero muy clara síntesis, en P. MOLAS, La monarquía española (siglos XVI-XVIII), Madrid 1990. 


\section{Etapa expansiva}

Oliva participa de la etapa expansiva generalizada española, y concretamente en el campo demográfico, se acerca al ritmo valenciano. Quizás la expresión de algunas variantes pueda ayudarnos a comprender mejor los matices concretos. La Guerra de Sucesión, con los cambios de soberanía y el carácter de guerra civil, explican la alta mortalidad de las dos primeras décadas, así como la baja natalidad y el escaso número de matrimonios. Sólo en la década de los años treinta se inicia un largo período de estabilidad de nacimientos y matrimonios que permiten superar la elevada mortalidad (excepto en 1748 y 1758 en que las defunciones superaron los matrimonios).

Este ritmo de crecimiento demográfico se hizo más acelerado desde 1761 a 1774 porque, a partir de esa última fecha, se hace visible una desaceleración hasta el extremo de que en 1772, 1779, 1783-1785, superaron las defunciones a los nacimientos. En conjunto el crecimiento demográfico a lo largo del siglo es similar al conjunto valenciano. Todos los testimonios parecen confirmar la existencia de una banda que evoluciona entre mil y mil docientos vecinos. Además de los censos de Aranda y Floridablanca, Mayans dirá a mediados de siglo que Oliva tenía algo más de mil vecinos y Cavanilles señalará en sus Observaciones la existencia de 1.206 vecinos, criterios que coinciden muy aproximadamente con los censos parroquiales. ¿Pero cómo vivían estos hombres que explique la posibilidad de ese crecimiento?

Se trata de un pueblo de señorío. Perteneciente a la familia Centelles, alcanzó una evidente plenitud económica en el siglo XVI, basada en el cultivo de la caña de azúcar. A partir de 1569 pasó a aumentar las posesiones de los Borja por el matrimonio de la heredera, Magdalena, con el hijo de san Francisco de Borja. Con la muerte de la última duquesa Borja en 1748, y después de un largo pleito, el condado de Oliva ( como también el ducado de Gandía) pasó a la familia Pimentel, conde de Benavente. Es preciso tener presentes los derechos señoriales par comprender muchos aspectos de la vida cotidiana de la población.

Otro factor esencial es su carácter agrario. El predominio de la agricultura era tan acusado que en la visita de Cavanilles, a finales de siglo, escribía: "y no habiendo en la villa fábrica alguna, ni más industria que la agraria". Ahora bien, dentro de los productos mediterráneos (cereales, aceite, vino, algarrobas...) se cultiva el maíz y, sobre todo, dos de especial relieve: el azúcar hasta 1754 y la seda que mantendrá su valor a lo largo del siglo.

\section{El indesmayable trabajo}

El ciclo laboral dependía absolutamente de la agricultura. En ese sentido los dos productos básicos señalan la evolución con sus ritmos de evolución diferentes: el azúcar en decadencia, la seda en expansión. Porque si el cultivo del azúcar sufrió un rudo golpe con la expulsión de los moriscos, las dificultades del transporte del azúcar americano con la salinización y el aumento del consumo permitieron su cultivo en Oliva a lo largo del siglo XVII y la primera mitad del XVIII. 
El cultivo era minucioso y requiría abundante mano de obra, especialmente en el sistema de riego adecuado para el crecimiento de las cañas. Segadas desde mitad de diciembre a Navidad, peladas, y dejados los tres o cuatro canutos últimos para plantel, las cañas eran transportadas al "enginy", donde empezaba el lento proceso de elaboración, minuciosamente descrito por Mayans: las ruedas que mueven dos muelas que aplastan las cañas, la recogida del zumo, su cocción y la purga, el depósito en las formas... Era trabajo delicado que requiría habilidad.

No menos atención exigía el cuidado de los canutos reservados como plantel. Se ataban en manojos y se colgaban, con la cola hacia arriba y rodeados de tierra. Debían regarse cada 15 días con cuidado, sin contacto directo de las plantas con el agua, hasta el momento en que se plantaban. A partir de ese momento venía el trabajo más delicado: arar, estercolar, establecer los surcos, frecuencia del riego... Si llovía por san Juan, las plantas aumentaban su tamaño y dulzura; si no llovía o el riego era deficiente, las cañas quedaban raquíticas y apenas producían el codiciado azúcar. Con mucho cuidado, una hanegada podía alcanzar 10 arrobas. Pero cualquiera descuido o deficiencia anulaba el esfuerzo.

Eso es lo que ocurrió con motivo de los pleitos sobre el derecho a utilizar el agua del Serpis, mantenido con los vecinos pueblos de Fuente de Encarroz y Potríes. Pese a ganar el pleito el municipio de Oliva, tanto en la Audiencia valenciana como en Madrid, con el reconocimiento del "condominio", los vecinos de Fuente de Encarroz cortaron el suministro de agua y la sequía mató las cañas. Fue el golpe de gracia. Porque, si el conde de Benavente, desconocedor del sistema, no proporcionó las plantas y, en el momento de repartir las ganancias, exigió más de lo acostumbrado, nadie pensó en esos momentos que el cultivo del azúcar había acabado. Así escribía Mayans a su amigo José Nebot: "Aún no es tiempo de cañas dulces, pues las de Oliva están en yerba. A su tiempo las tendrá. Las de Gandía, que se anticipan, nada valen" (11-XI-1752). Y años después, en 1758, el plebán de santa María, al explicar el sistema de diezmar, especificaba: "De azúcar, que puestas las cañas en la casa del ingenio, todo el coste es del señor, tira éste la mitad y de la otra mitad se paga el diezmo y primicia". Uno empieza a comprender los fabulosos ingresos que recibían los Borja del azúcar de la Safor. Si cada hanegada producía unas 10 arrobas y el señor se quedaba la mitad... Huelgan comentarios.

La desaparición del cultivo del azúcar dejaba unos meses de respiro en la actividad laboral de los olivenses durante los últimos meses del año, aunque trabajo no les faltaba. Porque durante noviembre y diciembre, tenían que ocuparse del aceite y de la sementera. En primer lugar, debía recogerse la aceituna, transportarla a la almácera, extraer el aceite. Así, sólo en la calle Mayor, existían 6 almáceras de propiedad privada, aparte de otras dispersas en otros lugares. En ese aspecto, Mayans podía enviar con generosidad una serie de arrobas del más selecto aceite a sus amigos madrileños (Martínez Pingarrón o Victor Comba). El aceite, que era un producto importante, no constituía la fuente económica esencial, aunque cubría las necesidades de la población.

Por otra parte, con dependencia de las lluvias otoñales, era la época de la semente- 
ra, además de podar las vides. Por cierto que la simiente de Oliva debía gozar de cierta fama. Porque, además del testimonio explícito de Mayans, he encontrado múltiples solicitudes de grano por forasteros. Hasta el extremo de que el médico Juan Heced, que ejercía en Museros y había cuidado a los hijos del erudito, agradece la simiente ofrecida al tiempo que indica las presiones que sufre de sus amigos para que se valga del favor de don Gregorio para conseguir simiente de trigo de Oliva.

Eran, sin embargo, los meses más tranquilos. Porque, apenas iniciada la primavera, aun antes de que finalizara el ciclo del azúcar, los olivenses ya habían encontrado otro producto básico: la seda. Y si las cañas se plantaban a mediados de marzo, apenas iniciado abril tenían que avivar los gusanos de seda. Era el inicio de una actividad trepidante que duraba hasta san Juan. Las moreras, que producían la hoja, estaban situadas generalmente al borde de los campos, dejando el interior para otros cultivos: trigo, habas, garbanzos, maíz. Y su cuidado exigía dedicación y habilidad: arado, uso del estiércol, riego en el momento oportuno, injertos.

El trabajo aumentaba con el despertar de los gusanos. La simiente de gusanos se guardaba el año anterior. Pero también se compraba y vendía por onzas y su cría iba acompañada de la recolección de las hojas y de su transporte a casa. No es menester decir que también la hoja se convertía en objeto de compra-venta. Los frecuentes cambios climáticos de nuestra primavera constituía un factor esencial y los riesgos eran evidentes. Si helaba la hoja, no podía darse a los gusanos que morían. Tampoco podía ofrecerse mojada y, después de la lluvia, debía orearse. "Son necesarios muchos para pelar (la hoja) y muchas mujeres o hombres para darles comer". Más todavía, el gusano no tolera excesivos fríos ni calores, era frecuente encender el fuego para calentar los locales o abrir las ventanas que permitieran refrescar el ambiente. Finalmente el ritmo de comidas era esencial para equilibrar el crecimiento de los gusanos que permitieran enramar al mismo tiempo: "un levísimo descuido echa a perder toda la cosecha y los grandes gastos hechos en ella". No creo necesario advertir que las casas se adaptaban a estas necesidades. Así, las conocidas cambras, o el piso superior de las casas, sin tabiques y bien ventiladas, eran necesarias para controlar el ambiente adecuado.

A lo largo de mayo, los gusanos enramaban y se convertían en capullos. Era el momento clave. Con rapidez debía procederse a hilar antes de que la salida de las palomas estropease el capullo. El trabajo debía ser rápido e intenso, porque del ahogado del capullo dependía el brillo de la seda. Se requiría mucha leña para mantener al fuego la "perola", una caldera de cobre ancha y de escasa profundidad, con agua a proporcionada temperatura que matara la crisálida y permitiera la extracción del hilo de seda. El trabajo era intenso y requiría habilidad. El jornal se hacía a destajo y, "además del jornal que ganan de real por cada libra de seda de doce onzas", se les daba desayuno, comida y cena. El salario a destajo debía ser habitual. Así, cuando en 1771, el Intendente obliga a utilizar ruedas para hilar que no pasaran de 12 palmos de circunferencia para los hombres y de 10 palmos para las mujeres, Mayans (de quien tomamos estas noticias) redactó el memorial de los sederos de Alcira, y alegó que la nueva reglamentación no contribuía a la delgadez del hilo y que disminuía la productividad en una tercera parte, mientras defendía el pago por libra de seda elaborada. 
No todo había finalizado con el hilado de la seda. El cosechero debía venderla y los problemas se acumulaban. Los distintos gobiernos centrales pretendían limitar (y hasta prohibir) la exportación de la seda con la finalidad de fomentar la producción interior. Este proteccionismo podría favorecer a los fabricantes, pero no a los cosecheros. Aparte, claro está, del negocio de los comerciantes e intermediarios.

Porque se transgredía la ley y con facilidad se exportaba la seda, especialmente en los puertos marítimos. La llevaban en pequeños barcos y la depositaban en parajes adecuados o en los barcos de mayor calado a la hora convenida. Al margen de los negocios propiciados por los comerciantes (no había ninguna fábrica en Oliva) los comerciantes pactaban con las autoridades locales. Los alcaldes y regidores dictaban el precio a que se podía comprar y la fecha inicial. En principio retrasaban todo lo posible la orden, al tiempo que pregonaban que nadie vendiera antes de establecer el precio, con amenazas de multa. Este retraso dañaba a los propietarios, cosecheros y arrendatarios. Porque la fecha clave para pagar arrendamientos, censos y equivalente era el día de san Juan (24 de junio). De ahí la necesidad de dinero. Pero cuando llegaban los comerciantes no convenidos, las autoridades alegaban que el precio ofrecido era bajo o que no traían bastante dinero, con lo que, aburridos, marchaban. Los más necesitados vendían la seda a los mismos regidores, directamente o por medio de sus intermediarios, a un precio inferior. Así, cuando llegaban los comerciantes "paniaguados" y dictaban el precio oficial, ya tenían comprada la seda a un precio inferior (Escritos económicos, pág. 99-100).

Estos días de intenso trabajo y de negocios por la venta de la seda coincidía con la siega del trigo. Era un trabajo agobiante por el calor y la premura de tiempo: siega, traslado por medio de caballerías, almacenamiento de las gavillas en las eras, la trilla... He encontrado la descripción hecha por el administrador del canónigo Mayans del incendio producido en una de las eras cercanas al pueblo. El 23 de junio de 1789 ardieron varios montones de gavillas. La confusión fue inmensa: el toque de las campanas de iglesias y conventos, la propagación del fuego a las casas vecinas que cerraron las ventanas, colocando sábanas mojadas, las carreras de gentes que sacaban agua de los pozos, aunque no había una gota en "la sequia mare" que servía para el riego, el temor a que se propagase a los montones preparados para la trilla en las calles adyacentes... Ardieron unos 150 cahíces de trigo. "Y esto se debe todo a los señores fumadores, pues se encontró un pedazo de soga que tenían de prevención". Naturalmente, todos los que estaban trillando fueron encarcelados. En muchos casos debió notarse falta de mano de obra y surgió la idea de una cierta mecanización, aunque fuera rudimentaria. Este fue el caso de Andrés Siscar, personaje sobre el que volveremos, dueño de una era, que solicitó una máquina para limpiar el trigo, aunque no da más explicaciones sobre las características (5-IX-1768).

Con la descripción de los trabajos relacionados con la seda y el trigo, he dejado otros trabajos agrícolas. La preparación de la tierra destinada al cultivo del arroz: la limpieza de las malas hierbas de la cosecha anterior, el arado de la tierra, la inundción de las parcelas destinadas a la siembra (hacia el día de san José), el arranque del plan- 
tel y la "plantá" que tenía lugar a lo largo del mes de mayo. Era este un trabajo especialmente duro, por desarrollarse dentro de tierras inundadas, y bien retribuido.

Ahora bien, apenas finalizada la siega del trigo, el agricultor olivense se veía sumergido en una época de ininterrumpida actividad. Especial relieve alcanzaba el maíz, cuya siembra, a principios de julio, exigía la concesión previa del riego del agua del río de Alcoy, o Serpis, que permitía el riego de los campos más fértiles.

Y junto al agua, el estiércol. Cavanilles, al señalar la gran extensión de tierras dedicadas al cultivo del trigo y maíz, añadía que los agricutores olivenses "necesitan mucho estiercol y abonos, y no bastando los conocidos en otras tierras, acuden los labradores a la que arroja el mar, conocido con el nombre de alga, que es la zostera mediterranea de Linneo". También Mayans habla de la necesidad del estiércol para el cultivo de las moreras. En consecuencia, además de las algas marinas, el agricultor recurría al estiércol producido por los gusanos, las caballerías y las aves del corral. (Las casas tenían en el corral un sumidero impresionante para recoger las aguas de la lluvia que fermentaban todos los residuos de personas o de animales, de la alimentación o de los restos de las hierbas del campo depositadas). El estiércol era un producto esencial para la agricultura y su exportación estaba prohibida por el derecho foral. Prohibición que, según Mayans, no había sido derogada por el decreto de Nueva Planta: "Me acaban de decir que la causa sobre la extracción de estiércol de esta villa contra las antiguas ordenanzas de ella están en poder del relator Gascó...; para que sentencien que las ordenanzas se mantengan en vigor, pues así está prevenido en la Pragmática que abrogó los antiguos fueros de este reino" (18-IX-1777). Como el estiércol debía esparcirse antes del riego, el ritmo de trabajo del verano dedicado al maíz, las moreras o el arroz, era ininterrumpido.

Los agobios se producían a finales de agosto y durante el mes de septiembre. La siega del arroz, cultivo caro, pues los jornales se pagaban a 7,5 reales castellanos, con la extracción de gavillas, la trilla, limpieza y almacenamiento del grano, requiría la colaboración de todos los miembros de la familia. Muchas veces era especialmente molesta si coincidía con las primeras lluvias otoñales. Al mismo tiempo había que recoger el maíz, las algarrobas (producto esencial para la alimentación de las caballerías), la recolección de la uva, de las almendras y los higos. Era una época de especial intensidad laboral, paralela a la de junio. En ambos casos se veía agravada por la necesidad de recoger la paja, en especial la de maíz, porque constituía producto clave en la alimentación de los animales de carga, y en determinados momentos constituirá motivo de fricción con el Intendente y los militares.

Una expresión de la actividad laboral en el campo olivense podemos encontrarla en una costumbre establecida por los hermanos Mayans desde que trasladaron su casa a Valencia en 1767, con motivo del nombramiento de Alcalde de Casa y Corte. A lo largo de septiembre de cada año, uno de los hermanos se trasladaba a Oliva, atendía a la recolección de los frutos, conversaba con el procurador de las tierras, cuidaba de las necesidades domésticas o económicas y transportaba a Valencia los productos necesarios para el sustento familiar. Lo curioso del caso es que el transporte se hacía por bar- 
co, que alquilaban en Valencia (costaba 17 libras) y, después de cargar en la playa (no había puerto), regresaba con los productos agrarios familiares.

Poseemos varias relaciones de los cargamentos. Así en septiembre de 1777 (saldría el día 21) embarcaron 3 pellejos de aceite con un peso de 15 arrobas, 22 cargas de algarrobas, 24 calabazas, barchilla y media de maíz, 1 capazo de granadas, 3 barchillas y media de almendras con 2 cuarterones de sémola, 2 onzas de dulce, 9 gallos, 16 talegas de harina, media arroba de sebo, 1 capazo de pasas, otro de pasas y garbanzos, uno de frísoles, 1 barchilla de almidón, 1 capazo de melocotones, 1 talego de edros y 90 melones. A todo ello añadieron 2 melones para Luis Meseguer y 3 para los marineros. Para mayor conocimiento del peso de las cargas de algarrobas, en el embarque de 1774 indicaba Juan Antonio: "30 cargas de algarrobas de 10 arrobas cada una". Claro que el mayor o menor cargamento se debía a las necesidades familiares o a intereses personales. Por eso en 1774 había más trigo ( 6 cahíces y medio, más 1,5 para el diezmero) y maíz (98 barchillas), 18 arrobas de aceite y cuatro quintales y medio de pasa, mientras disminuían los melones ("20, o más, se verá").

Naturalmente, no todos los productos del campo tenían carácter comercial. Muchos, especialmente la fruta, constituían un gusto personal o de obsequio amistoso. Así, en uno de los viajes de septiembre de la familia a Oliva, fueron las hijas del erudito que serían obsequiados con la invitación a "las parras" de los amigos y quedaron tan contentas que se invitaron para años siguientes. A decir verdad, era frecuente el obsequio de un capazo de fresas, cerezas, manzanas o peras, que eran enviadas en los medios de transporte ordinarios a la capital.

Todo este ritmo agrícola podía verse trastocado por accidentes meteóricos: excesivas lluvias o pertinaces sequías. Hay frecuentes testimonios de inundaciones (1744, $1763)$, sequías $(1657,1698,1738)$ con las habituales rogativas y procesiones con las imágenes de los santos patronos. Pero el mayor peligro era, sin duda, la langosta. En 1708, aparece una nota en el Manual de diferents coses del archivo parroquial de santa María, comunicando las rogativas por el azote de la guerra "y demes calamitats (que) nos amenaçava y alcansava el azot de la justicia del Señor en una plaga de llagosta que menasava talar tots los fruits".

La plaga duró del 26 de julio al 5 de agosto. Eran los días habituales y coinciden plenamente con los de 1756 que conocemos a la perfección, gracias a la minuciosa descripción de Mayans, que publiqué en Escritos económicos. El 21 de julio aparecieron a bandadas, como los copos de nieve dirá el erudito, movidas por el viento de poniente. Devoraron toda hoja verde, especialmente las verduras y la alfalfa y, aunque hubo convocatoria general para matarla, de nada sirvió. Mayans calculaba que, con los métodos rudimentarios de captura con sábanas abiertas y el enterramiento posterior, venían a capturarse 500 ó 600 arrobas diarias, pero apenas se notaba pues, a su juicio, había langosta para devorar el campo europeo. Se practicaron todos los recursos: cerrar los pozos, dejar correr las acequias, enterrar la recogida o la devuelta por el mar, pese al hediondo olor que ponía en peligro la salud de los vecinos.

A mediados de agosto, la langosta iba muriendo, pero dejaba "el canutillo" que re- 
viviría al año siguiente. $Y$, además, dejaba una secuela de pobreza y miseria. Tanto que los regidores encargaron a Mayans la redacción de dos memoriales: uno dirigido al monarca, otro para el señor (conde de Benavente), solicitando el aplazamiento del pago del equivalente del año 1757 pues, dado que los vecinos no podían contribuir, los regidores se veían apremiados a dar personalmente el "cumplimiento al pago". Más aún, a la langosta se unió en 1757 la oruga. El erudito solicitaba en concreto que los mismos regidores continuaran en sus cargos otro año para poder recoger la cantidad exigida para el equivalente.

De creer a Cavanilles, sólo había en Oliva trabajo agrícola: "y no habiendo en la villa fábrica alguna, ni más industria que la agraria". Sin embargo, un memorial de Mayans, dirigido al rey en nombre de la villa, nos demuestra la existencia de un grupo de mujeres "tejedoras". Más de 115 mujeres compraron un telar, "solamente cuesta a cada una dos doblones", que les permitía tejer productos bastos, lienzo casero pero de mejor calidad que el vestido de los soldados. El tejido podía alcanzar 3 palmos de amplitud, a 12 dineros la vara, o 3 palmos y medio a 15 dineros. El sistema económico en que se basaba el trabajo era muy elemental: "las cuales tienen el arbitrio de dar a hilar, pagando esta labor con el valor de la tela correspondiente; y otras veces cobran con jornales de arar sus tierras, con trigo o legumbres, higos, pasas y otras cosas comestibles, o fían las telas, esperando el tiempo oportuno de las cosechas; y de esta manera todos remedian sus necesiddes por medio de la permutación, por lo cual evitan recoger el dinero, que a muchas de ellas y a sus maridos sería imposible pagar de contado y logran un fácil y útil comercio con la mayor comodidad". Mayans consiguió la licencia de la Real Junta General de Comercio para que las tejedoras de Oliva continuaran libremente su trabajo, pese a la oposición del gremio de tejedores de Valencia. La actividad textil continuó, pero nunca superó el nivel expuesto en el memorial mayansiano y toda la actividad laboral olivense se ha orientado hacia y por la agricultura hasta nuestros días.

Cualquiera que haya seguido la exposición anterior habrá podido observar la importancia del agua para las labores agrícolas. Dado que el clima mediterráneo no se caracteriza por el ritmo regular de lluvias, se hace necesario el riego. En efecto, el sistema de riego, esencial para el conocimiento de la agricultura valenciana, ha sido estudiado por historiadores nacionales y extranjeros y de su importancia baste recordar el Tribunal de Aguas. Pero no es este mi objetivo. Ni siquiera pretendo analizar los problemas jurídicos suscitados con motivo de los pleitos, más que seculares, entre las poblaciones de la conca de la Safor por el uso del agua del Serpis, para el riego de la caña de azúcar, las moreras o la naranja. El pleito venía arrastrándose desde 1511 y todos los pueblos se vieron implicados. Problemas de aplicación hubo en el XVII, como demuestra la tesis de Santiago La Parra sobre el ducado de Gandía. Y los problemas jurídicos del XVIII aparecen minuciosamente descritos por un protagonista directo en los pleitos y que publiqué en Escritos económicos.

Dejo, por tanto, al margen el problema legal y señalo la importancia del riego del agua del Serpis para la agricultura olivense. Era esencial para regar la caña de azúcar, la morera, el maíz, los cereales, verduras, forrajes... En consecuencia, cualquier retraso 
en el reparto del agua constituía una tragedia para los campesinos. La "sequia mare" era el conducto básico por el que discurría el agua del río, ramificada después en una tupida red de canales, que era rigurosamente distribuida en el término de Villalonga. Ahora bien, en años de sequía, resultaba muy fácil a los pueblos más cercanos al río (Fuente de Encarroz, Potríes...) impedir la distribución asignada y aprovecharse del agua destinada a regar la huerta olivense. De ahí el interés de Mayans en demostrar en el pleito que siempre se había regado del Serpis.

Pero no todo el término era regado por el agua del río. La descripción de Mayans permite vislumbrar que había ido añadiéndose nuevas partidas. Así, entre las siete partidas señaladas, aparece una cuyo nombre es todo un símbolo: "rec nou", riego nuevo. Y, por supuesto, otras zonas de nueva ampliación agraria no podían regarse del Serpis. Ya Cavanilles fue consciente del hecho, al señalar, además de los huertos, seis mil hanegadas de marjales, espléndidas en sus cultivos, que fueron posibles gracias a otros sistemas de riego.

Para comprender las dos formas típicas de riego, es preciso tener presente la existencia de una red de acequias por las que discurría el agua en un plano inferior a los campos. El problema consistía en elevar el agua al nivel de los huertos. Además de la clásica noria, había otros dos medios. Uno de los medios utilizados era el rec de carabasí, que ha perdurado hasta pleno siglo XX, y así descrito por Cavanilles: "Hállase el agua en los azarbes... y los campos a cuatro, cinco o más pies de altura sobre el nivel de ella. Para regar cada jomal de tierra se destinan tres hombres, de los cuales dos se ponen junto al agua, y con la calabaza que cada uno tiene, muy parecido a un cazo por el largo y angosto cuello de ella y la concavidad profunda de la barriga, sacan agua del azarbe y la vacían en el campo, donde muy pronto forman un arroyo por las frecuentes y continuadas cantidades que dejan; corre entonces el agua por el reguero dispuesto de antemano, desde el cual el tercer hombre, llamado encaminador, la dirige oportunamente a los cuadros" (Observaciones, n. 147). Huelga decir el esfuerzo humano exigido para regar las seis mil hanegadas señaladas por Cavanilles, teniendo en cuenta la frecuencia quincenal del riego y, sobre todo, si había que duplicar la operación del rec de carabasí, en caso de la extrema elevación de los campos sobre el nivel del agua.

No menos esfuerzo exigía el otro sistema de riego: el de tahona. Se trataba de un artilugio de madera entre 4 y 5 metros de longitud, según la profundidad del agua, en forma de canal, de unos 30 centímetros de anchura y 20 de profundidad. Clavada en el margen de la acequia por el centro, conseguía el balanceo necesario para sumergir la parte inferior en el agua, cuya presión abría una hendidura de modo que el recipiente, al ser levantada por la fuerza de dos hombres colocados en la parte superior, se cerraba y permitía depositar el agua en el campo. Exigía, por tanto, abundante mano de obra, al menos tres personas, pues, además de dos hombres que movían la tahona, era necesario el encaminador que dirigisse el agua a los cuadros. Como puede observarse, los preciosos huertos que admiraba Cavanilles eran el fruto del abnegado esfuerzo y denodado trabajo de los campesinos. Porque el riego era esencial para la agricultura. Tanto que, en repetidas ocasiones, aparece el proyecto de utilizar el agua del Bullentó, o sequia del Vedat, para el riego de zonas de secano. Juan Antonio Mayans fue invitado a 
una reunión en el Ayuntamiento, y Cavanilles insinúa la conveniencia de desviar el río por el rincón de San Pedro como el lugar más idóneo.

\section{La comida. Necesidad y placer}

Sin los medios actuales de transporte y sin adelantos técnicos para conservar los productos perecederos, el sistema de comidas estaba, en gran parte, limitado por la agricultura local o de las cercanías. La mejor composición de lugar en este aspecto podemos adquirirla con la descripción de los diezmos, según la encuesta de 1758: "Diezmos de trigo, adaza..., de uva de vino, de todo género de legumbres y habas..., del azúcar, de higos, de aceite ..." En el análisis concreto de cada producto aparecen, además, almendras, aunque "son pocas", la pasa, los corderos, hortalizas y uva para vender. Esos parecen, por tanto, los productos agrícolas y ganaderos más importantes que servían para la alimentación básica, además del arroz que no aparece en la relación.

En una decripción, un tanto idílica, Mayans exponía la fertilidad de la tierra: "En todos los meses del año se cogen frutos útiles para mantener la vida humana, todos con grande abundancia; pero ciñendo el asunto a las cosechas de trigo y maíz, aquel es tan escogido que de quince y más leguas vienen a buscarle para sembrar, por ser tan certero, y en cuanto al maíz se provee de él el marquesdo de Denia y muchas poblaciones de las montañas vecinas, quedando esta villa totalmente abastecida para su sustento" (10-XI-1753). Esas palabras responden al interés gubernamental por establecer un pósito de trigo en Oliva como en las poblaciones inmediatas. Pero el contenido requiere algunas precisiones. Es bien sabido que el trigo fue siempre escaso en el antiguo Reino de Valencia, que debía abastecerse con importaciones, especialmente por transporte marítimo. También en Oliva podía observarse con frecuencia las dificultades de abastecimiento. Así, en 1750: "Si con el tiempo no se da providencia para que venga trigo a España, habrá un año malísimo. Ya tengo el que he menester (que son 20 cahíces) a nueve libras el cahíz salido de las eras, precio que en esta villa años ha que no se ha visto tan subido" (4-VII-175)). Son palabras escritas en julio, en plena cosecha.

Existía, además, otra dificultad añadida: la humedad del clima que impedía conservar el trigo de un año a otro. Esa fue una razón básica alegada por el municipio para oponerse a establecer el pósito. Claro que existían otras razones como falta de caudales para construir un local adecuado, dificultades para una justa distribución entre los vecinos o el temor a que el establecimiento del pósito produjera más perjuicios que ventajas en clara alusión a los frecuentes latrocinios. Pero, entre las razones alegadas, aparecen una serie de datos de singular relieve sociológico. "A esta fertilidad natural es correspondiente la económica y la manera de vivir de los vecinos de esta villa, en la cual solamente hay unas veinte y cinco o treinta casas, a lo más, que comen pan de trigo, todos los otros de maíz, porque comiendo menos harta más" (10-XI-1753). Sin duda, no se trata de la única razón, ni seguramente de la verdadera causa. Porque las veinticinco o treinta familias que comían pan de trigo eran los potentados del lugar. "Los más ricos, que todos procuramos abastecer nuestras casas del trigo suficiente para todo el año". Más aún, unos años después, al analizar las razones del crecimiento del 
uso del pan de maíz, alegará que "los tributos y calamidades de nuestros tiempos le han hecho tragar a los valencianos" (4-II-1765).

Dado que no existía pósito, la necesidad de conservar harina de trigo y de amasar el pan, quedaba resuelta con la existencia de dos alhóndigas, una en la villa y otra en el arrabal, y dos panaderías igualmente distribuidas. Sus propietarios estaban obligados a tener preparados durante todo el año la harina o pan que los vecinos y transeuntes necesitaran. Una ventaja encontraba el erudito en este sistema: siempre parecían más independientes de las autoridades locales y al margen de posibles manipulaciones, al tiempo que "el público tiene una total seguridad del abasto, que está a cargo de los arrendadores de las panaderías y alhóndigas y de sus fiadores, hombres abonados y de conveniencia".

Era criterio generalizado que en el siglo XVIII era más fácil que en siglos anteriores suplir la tradicional carestía de trigo. "Felipe II no conoció el maíz, el cual hace que en estos países no pueda haber hambre". Tenemos, por tanto, en el cultivo del maíz una de las razones que permitieron vencer el hambre de la población. Eso explicaría su rápida difusión. Porque si en una villa de cerca de mil vecinos, sólo unas decenas de familias comían pan de trigo, el resto debía alimentarse fundamentalmente de maíz. Y esa parece la proporción generalizada de Valencia. Así, en 1765, al tratar sobre la libertad del comercio de granos, Mayans señalaba la dificultad de conocer el número de personas que consumían trigo en España, porque había dos grandes excepciones: "es a saber, los vecinos de Galicia y de Valencia. En este último, de cada treinta personas (por no decir cuarenta) hay solamente uno que coma pan de trigo y los demás le comen de adaza" (4-II-1765). En consecuencia, aconsejaba el cambio del cultivo de trigo por el de maíz, "donde la naturaleza y el arte lo permita... Sesenta años atrás era raro en el reino de Valencia el pan de adaza; los tributos y calamidades de nuestros tiempos le han hecho tragar a los valencianos".

Esto quiere decir -aparte de la noticia sobre el ritmo de implantación del maíz, creciente después de la Guerra de Sucesión- que el pan de maíz era considerado un mal menor. Los ricos lo comían de trigo y sólo las calamidades y los impuestos obligaron a los valencianos a aceptarlo. Por lo demás, el cultivo de maíz tenía ventajas. Su rentabilidad era grande -mayor, por supuesto, que el trigo- y sus desperdicios servían tanto para alimento de las caballerías como para producir estiércol, esencial para el agricultor de la época. Todas esas razones nos permiten comprender el aparente contraste entre la afirmación de que el cultivo de trigo en Oliva era rentable y de alta calidad, hasta para ser buscado para simiente en los pueblos vecinos (demostrado por frecuentes solicitudes) y que la mayoría de la población comiera pan de maíz. Porque se ha dado hasta tiempos más cercanos el hecho de cultivar trigo para vender, por su alto precio, y comer en la familia pan de maíz. Eso explicaría las palabras del erudito: "Ya tengo el que he menester (que son veinte cahíces) a nueve libras el cahíz salido de las eras, precio que en esta villa años ha que no se había visto tan subido".

Había en la comida de los olivenses otro producto básico: el arroz. El aumento demográfico explica el aumento de producción y tenemos múltiples testimonios de que 
era un factor esencial en la alimentación. "El arroz es la comida más usual de los labradores deste reino, y aun de los que no lo son, porque alimenta mucho siendo en sí especie de pan y se cuece presto y con poca leña, sin necesitar de más añadidura que sal. Cuando abunda es la comida más barata, y comida de todos tiempos. Si va muy caro, no hay con qué suplir su falta... Es comida, pues, necesaria y útil" (23-III-1757). En efecto, el erudito tenía razón y ha sido -y continúa siendo- alimento básico. Dado que la población vivía de la agricultura y el jornal era desde la salida a la puesta del sol, el arroz se preparaba para la cena familiar, al regresar el padre de familia del campo. Y era "comida de todos los tiempos". Porque el arroz podía combinarse con los productos agrícolas de cualquier época del año: habas, garbanzos, verduras, carne, bacalao (para los días de abstinencia).

Esa pluralidad de posibilidades de cocina permitía el aumento de uso y suplía, en gran parte, la carestía del trigo; "siendo en sí especie de pan", decía el erudito. En consecuencia, tiene una lógica explicación el aumento de su cultivo, pese al elevado gasto de la producción y las enfermedades, la terciana o malaria, producida por el agua estancada. Será una disyuntiva que no disminuirá la producción, ni la comida. En ese sentido, la familia Mayans, cuando ya residía en Valencia, recibía, en enero de 1781 , tres barchillas de arroz desde Cullera, a 3 libras y 15 sueldos por barchilla, de parte de un tal José Renart que le regaló un par de patos de la Ribera. Resulta claro que el arroz era también alimento básico para personas que no eran agricultores.

No hay duda de que los olivenses comían mucha carne. Era producto deficiente en el antiguo Reino de Valencia y resulta lógico que cada población buscara abastecer al máximo sus necesidades. En este sentido, prevalecían los corderos y las aves de corral. Hay pruebas de que en el siglo XVII se exportaba gran cantidad de lana: 210 arrobas en 1635,600 al año siguiente, 110,5 y 24,5 cargas en 1642 y una media entre 330 y 400 arrobas a mediados de siglo. Además, hubo protestas y, consecuencia, acuerdos municipales, aprobados por el señor, para castigar a quienes llevaban los ganados a pastar en campos ajenos. Así, en 1676, el Consejo municipal acordó aumentar las multas a quienes permitían a sus ganados (ovejas, cerdos o vacas) penetrar en otros campos a los suyos. Casos similares podemos observar en el siglo XVIII: bueyes que pastan, multas a los pastores que introducen las ovejas en sembrados...

Y en cuanto a las aves de corral, la abundancia de datos demuestra la existencia aun en las casas más linajudas- de gallinas y pollos que eran utilizados para comida o caldos. Bastaría recordar que los Mayans, en el barco que fletaban por septiembre, cargaban un número elevado de pollos: 9 gallos en 1777, o simplemente "las aves", el recuerdo de Juan Antonio a su sobrino Miguel para que cuidase de los mulos y de los "gallos del corral". No resisto la tentación de transcribir un texto muy expresivo. Al notificar el erudito al médico de Valencia la enfermedad de su hijo José, de 22 meses, comunicaba que mamaba y comía mucho. Al destetarlo repentinamente, "por quererlo así el marido de la ama de leche", aunque de día no se acordaba de la nodriza, la echaba de menos por la noche. Para que no llorase, su madre "le hacía vestir y bajar a la cocina donde le daban chocolate a las dos o las tres de la noche... De comer le daba cuanto quería, carne, gallina, sopas una escudilla detrás de otra. Desta suerte, aborreció la 
carne, la gallina y las sopas y también el caldo" (4-XI-1752). No extraña que fuera necesario el viaje de un discípulo del Dr. Piquer para curarlo.

Ahora bien, una serie de testimonios relacionados con el arriendo de la venta de carne y de la sisa demuestran la cantidad de dinero que se manejaba en su comercio, los negocios no siempre limpios y las protestas de los ciudadanos por las implicaciones no siempre claras de los regidores. Así en una pesimista descripción de los efectos de la actitud contemplativa de las autoridades, Mayans se explica con dureza: "...causan al público unos daños irreparables, cuales son los que hacen los ganados a vista de todos, lo que muchísimos hurtan en los campos, teniendo sus casas abundantemente abastecidas, la carne mortecina ocultamente substituida por sana; todo lo cual saben y toleran los alcaldes y que estos daños importan más de veinte mil pesos al año" (25-VI-1764).

La apreciación global del erudito puede parecer en principio exagerada. Pero poseemos un testimonio posterior, concretamente de 1767, en que había empezado a actuar el síndico personero, que viene a confirmar los anteriores juicios. Así el 18 de mayo ya expresaba Andrés Siscar, personaje vinculado a la administración municipal y del que luego hablaremos: "Aquí hay un enredo sobre carnes fuerte y han dado unos testimonios que están comprometidos de pies a cabeza". El enredo fue aclarándose o complicándose, como se quiera. El problema se centraba en el abastecimiento de carne de oveja y la cantidad era tan elevada que los implicados por parte del ayuntamiento desearon se pagara con las rentas municipales. "Sobre el abasto de medio año de la carne de oveja, que importarán más de mil libras, y tiran a que los sucesores en el gobierno lo cubran de las rentas del común; hay un laberinto sobre esto, sin la que tiene instada Francisco Salort sobre la del carnero, en que les da bastante que hacer" (20-XII-1767). El asunto podría agravarse, si los nombrados en el nuevo equipo de gobiemo, especialmente el diputado y síndico personero, "sale opuesto al actual y su pandilla, como se espera". Dejemos el asunto de la actuación de los diputados y síndico personero, y observemos el arriendo de la venta de carne de oveja de medio año en más de mil libras. Supone evidentemente una gran venta de carne para uso de los vecinos.

$\mathrm{Ni}$ que decir tiene que muchas familias mataban su cerdo, lo que propiciaba la elaboración de embutido. "Ayer mataron el cerdo", escribe Juan Antonio el 4 de febrero de 1773. Más interesante resulta quizás la enumeración de los productos alimenticios que podían adquirirse en la tienda que abastecía de pan y de harina, cuyo propietario se comprometía "dando fiadores competentes" y con multas si faltaba el abastecimiento. Pero, junto al pan y harina, en la tienda podía comprarse aceite y arroz, bacalao, atún y sardinas.

Entre los productos alimenticios generalizados, frutas (naranjas, fresas, cerezas, manzanas de verano e inviemo, peras, higos, uvas y pasas, almendras, melones -hasta castañas, como recuerda una hija del erudito que se vendían en noviembre en la calle mayor- ), hortalizas (habas, garbanzos, alcachofas...) o escabeche familiar, es necesario aludir, con la máxima brevedad a dos productos de especial relieve: el dulce y la sal.

En zona de eminente tradición azucarera resulta lógica la comida, quizás excesiva, de dulces. Las referencias son constantes. Frecuentes regalos de tartas o bizcochos es 
la manifestación cotidiana en la correspondencia: las monjas de clausura que obsequian con una "tortada", el envío apresurado de un bizcocho aprovechando la llegada de un amigo o el viaje a Valencia de un conocido. En un momento concreto podemos leer: el bizcocho se hizo en una hora, pero, por ser de Oliva, saldrá bueno (1774). Un dulce curioso que merece anotarse: "Las muchachas y Pepe dicen que se han de confitar las naranjas o con miel o con azúcar", sin mayores explicaciones (1775). O, no menos significativo, el párroco de Castelló de Rugat les obsequia con "seis orcicas de arrope" (1768).

Pero, sin duda, el dulce por excelecia en el siglo XVIII era el chocolate. Por las referencias en cartas y aun en dietas de médicos, da la impresión de que se puede comparar con el uso actual del café. En principio, Mayans escribió en su juventud un poema latino como homenaje al sabroso líquido, Chocolata, sive de potione indica (1732). Y debió ser un empedernido bebedor de chocolate. Aparte de numerosas alusiones al uso en el desayuno, hay un matiz que revela su pasión por el chocolate. Cuando el marqués de la Ensenada le quiso obsequiar por sus colaboraciones intelectuales, entre otras con la redacción de las Observaciones al concordato de 1753, el erudito no quiso aceptar tabaco ni vino. Recibió en cambio chocolate y quina. He aquí su comentario: "Pero, en fin, S. Ex. obra como quien es, y quiere que yo también sea liberal. Del chocolate no lo seré porque, habiéndole probado, me gusta mucho y ningún fraile se gloriará de beberle" (3-III-1753). En consonancia con estos gustos, el meticuloso erudito, ya viejo, recordaba a su familia que, entre los enseres preparados para el viaje de su hijo a Granada como Alcalde del Crimen de la Chancillería, debían incluir un "cajoncito de chocolate para el refresco; arroba y media de dulce repartida". Era la expresión del placer tradicional que había experimentado cotidianamente en su villa natal. Más todavía, en Oliva lo elaboraban personalmente. Así se deduce de unas palabras de Juan Antonio: "Hoy miércoles hemos labrado chocolate". Y debió ser en cantidad, porque lo colocaron en la casa de la calle Mayor y dieron a su anciana tía 18 libras (sept. 1774).

La sal constitúa otro mundo, y muy complejo. Era monopolio estatal y se convertía en un tributo más. Un primer acercamiento al sistema de distribución nos lo proporciona Mayans. Si bien salva la buena voluntad del rey, lamenta que se les obligue a tomar en mayor cantidad de la necesaria, llena de tierra y de mala calidad. Pensar en un recurso no tiene sentido, pues "sería cien veces más costoso que el daño, aunque tan grande". La culpa, en el fondo, recae en los regidores de quienes dependía el encabezamiento, que se reparten la sal como quieren "y cargan a todos los demás" (29-III1749).

Pero será Andrés Siscar quien, desde su cargo en la administración municipal, nos aporta datos preciosos sobre el sistema de reparto. El 13 de febrero de 1769 solicitaba, por medio de Mayans, información de Ginés Boix, visitador de las reales rentas de tabaco, porque habían repartido excesiva cantidad, cuando mucha gente ya tenía para todo el año. Reconocía que el sistema producía beneficios a la administración real, "pero la mayor parte en favor del salinero... y poniéndola en administración", como lo estaba antes y ahora en Gandía, sería más justo. La raíz del mal estaba en la cantidad repartida que a la larga repercutía en perjuicio del común. Andrés Siscar, por esas fe- 
chas alcalde ordinario, creía adecuada la cantidad destinada a las personas, pero sobraba la que les obligaban a tomar para las caballerías y el ganado, porque en Oliva no era necesaria, "por la razón de ser la tierra marina en donde las yerbas son salobrencas" (19-II-1769).

Unos meses después, don Andrés lamentaba la terquedad del administrador de la sal que de ningún modo quería ceder. Más todavía, en abril de 1770 , siendo teniente de alcalde mayor, comunicaba haber recibido despacho del Intendente de Valencia quien, a solicitud del administrador de la sal, les obligaba a pagar toda la sal que se les había destinado, aunque no la habían recibido por no ser necesaria. En el fondo, pensaba, era una venganza por las diferencias mantenidas por el municipio, y en concreto por don Andrés, contra la decisión del Intendente y de los asentistas de obligarles a ofrecer paja para los caballos del ejército (7-IV-1770).

\section{Una deficiente sanidad}

Nadie puede dudar de que el trabajo agrícola y el sistema de comidas repercuten de manera decisiva en la salud y en el tipo de enfermedades más frecuentes. Claro que un profano en la ciencia médica, como yo, no puede entrar en el análisis de los aspectos técnicos. Quien así lo desee tiene a su alcance las noticias que Vicente Peset aporta en el Epistolario de Mayans y los médicos, aunque centró su interés en el influjo mayansiano respecto a los orígenes de la historia de la medicina entre nosotros. Por mi parte, basado en los datos recogidos por Peset y en otras cartas, no dirigidas específicamente a médicos, intentaré más bien una aproximación sociológica a la sanidad de los olivenses del XVIII.

Es menester confesar, desde el primer momento, que los hombres más cultos desconfiaban del nivel de conocimientos de los médicos rurales. Mayans que, como veremos, recurrió en numerosas ocasiones a sus amigos de Valencia, entre otros al Dr. Andrés Piquer, para consultar sobre las enfermedades de su mujer e hijos, lo expresaba con gran plasticidad: "También deseo saber qué practicaremos; porque aquí hay cuatro que se dicen médicos. Pago al uno para que no venga. No pago al otro para que no venga. Otro que pago no sirve. Y el otro sólo aprovecha para ver cómo son los títeres" (M. a Nebot, 5-XI-1746). Estas duras palabras, expresadas en general, encuentran su confirmación en casos concretos: "El Dr. Hermán fue recibido de su primo el Dr. Masquefa como tercianario; éste se valió de un cirujano, que le dio dos estocadas, y anoche murió" (29-V-1744). O en las no menos sangrientas referidos al mismo médico: "Si me hubiera creído (Monzonís) antes hubiera ido a esa ciudad (Valencia) a ser tratado por el Dr. Piquer, huyendo del Dr. Masquefa, que es más cruel que un ejército de caribes" (9-VI-1751).

Médicos y cirujanos son acusados con frecuencia de ignorantes por los mismos galenos. No sólo en Oliva, por supuesto. Pues el Dr. Heced, discípulo de Piquer, comentaba con amargura la ignorancia del médico a quien recurrió en enfermedad propia, en este caso en Museros (5-I-1756). Y no menos duro el juicio de Piquer respecto a los ci- 
rujanos, a quienes nunca debería dejárseles cortar una duricie o clavo en los dedos del pie, porque "son unos bárbaros y por cortarlos indiscretamente han ocasionado graves daños" (21-XII-1746). Por lo demás, el intrusismo en el campo de la medicina estaba muy generalizado, especialmente por parte de los boticarios.

En esas circunstancias, resulta muy lógico el interés por conseguir un buen médico para el servicio sanitario de la población. Pero Mayans, que conocía por sus amigos (Piquer, Millera, Capdevila, Seguer o Millera) los progresos de la medicina moderna, deseaba un galeno instruido. En 1751 los abusos en la alimentación de uno de sus hijos le produjo tales problemas intestinales que se vio obligado a requirir el viaje de un médico desde la capital. La visita se encargó al Dr. Juan Heced, que estuvo unos días en casa del erudito, y resolvió los problemas sanitarios de su familia. Pero en los momentos de apuro, expresa toda la inquietud por la falta de atención médica de la población: "Todo esto estaría remediado si hubiera aquí un buen médico, y le habría si estuviera en mi mano, dejándolo yo en la de Vm." Habría que buscar primero el médico competente y después indirectamente el beneplácito de alcalde y regidores. "Si este medio pareciere a Vm. muy humilde, podría hacer D. Andrés Piquer que el Gobernador del Consejo escribiese a la villa, recomendándole alguno y encargando a la villa que convocase a los principales, y me parece que se haría algo. Esto en caso de tener Vm. alguno de su satisfacción a quien quiera acomodar. Me parece que se podrían asegurar ciento y cincuenta libras y manos libres" (4-XI-1752).

Estas palabras expresan con claridad la situación: malos médicos locales, dificultad de encontrar uno preparado, los problemas burocráticos para conseguir su aceptación, al menos con la seguridad de un decente salario. Esas gestiones del erudito, no creo haga falta decirlo, no fructificaron. Sin embargo, datos relacionados con la asistencia médica en la villa demuestran que la preparación científica de algunos médicos había mejorado. Así, en 1774, Juan Antonio, ya canónigo, pasó a Oliva a recoger los frutos del campo, pero también para atender a una tía enferma: "En boca del Dr. Blasco (el médico) se oyen los nombres de Boerhave, Van zu Wieten, Haller, Gorter etc.; dice de memoria pedazos de Celso" (4-VIII-1774). Pronto pudo observar el efecto positivo de la medicación y se apresuró a comunicar la diferencia de métodos entre el médico viejo y el joven. Y unos días más tarde revela el juicio que ha formado del médico y su temor a que vecinos y común no sepan reconocer su mérito y lo dejen marchar: "Dios nos ha librado de una gran tempestad. La sencillez de la medicina hipocrática obra efectos maravillosos. La sencillez de la medicina hipocrática obra efectos maravillosos. Blasco es un gran boheraviano y se le luce. Tiene y ha estudiado los médicos más célebres antiguos y modernos; y lo más singular es que él mismo se ha alumbrado. Mucho quisiera su establecimiento en esta villa cuadrupedal". Y decide obsequiarle con un libro de historia de la medicina, "De lue venerea de Astruch" (11VIII-1774).

Aludir a las enfermedades más frecuentes no siempre resulta fácil, pues en los Quinque libri sólo empiezan a anotarse en el siglo XIX: inflamación de vientre, hidropesía, convulsiones, desintería, gastritis, catarro pulmonar, tuberculosis, tercianas, 
asma, gangrena, apoplejía, cólicos, hemorragia, hepatitis, vómitos, problemas dentales... No creo resultaran muy diferentes las últimas enfermedades en el siglo anterior.

Porque en la correspondencia ordinaria aparecen esas enfermedades. Aunque, a decir verdad, la terciana ocupa un lugar especialísimo. Las consultas de Mayans a sus amigos médicos de Valencia están plagadas de referencias a miembros de su familia; mujer, hijos, criadas..., que sufren la enfermedad. Era fruto del cultivo del arroz y llegó a ser tan agobiante que hizo cambiar de criterio al erudito respecto al cultivo del arroz. Partidario acérrimo en principio, cambió de criterio después y condenó con energía el afán de enriquecimiento de algunos con desprecio de la salud de muchos. En sus Escritos económicos puede seguirse la evolución de su pensamiento. Debo decir, sin embargo, que no es sólo Mayans, ni en la década de los años sesenta. El Dr. Heced llegó a escribir que el clima olivense no era favorable, pero tuvo que confesar en otro momento que toda la zona marítima sufría de tercianas, también en Museros donde ejercía la medicina. Años después, en 1787, Pascuala Llopis, de Oliva, solicitaba una limosna al canónigo Mayans porque su marido había caído enfermo en la Ribera, donde había ido a segar arroz. Y el párroco de san Roque, del arrabal, escribía: "empiezan las tercianas hogaño, si no con tanta malicia como el pasado, pero a lo menos por ahora con más abundancia, de forma que parece Oliva el medio de la Ribera, por ser muchísimos los que caen todos los días, siendo aún tan temprano". En la carta, del 14 de julio de 1785, observaba que, de forma similar al año anterior, atacaba más a los pobres y de manera especial al convento. "Y esto, a mi parecer, son las desdichas de esta infeliz tierra, tanta pobreza (que le sacan a uno de tino, siendo tan malas las cobranzas) y esta la causa de toda especie de enfermedades".

Pero no siempre era la pobreza la causa de las enfermedades, ni éstas quedaban reducidas a la terciana. Lo sorprendente es que, tratándose de una enfermedad tan habitual, hasta Mayans recurriera de manera tan insistente a sus amigos médicos para que le dieran recetas y medicinas para curar a sus hijos. Porque frente a la solución más frecuente (sangrías y una purga), el erudito buscaba una medicación más racional, dada en este caso por Piquer: si el médico considera necesario "limpiar el vientre..., no consienta que lo haga con purgas, sino con un vomitivo ligero, de modo que tres gramos de tártaro emético con una cucharada de caldo la harán vomitar... Después de esto, es preciso darle la quina en polvos, no en tintura, y ha de tomar hasta tres dragmas, con lo cual creo yo quedará buena" (28-IV-1751).

Claro que las consultas no quedaban reducidas a la terciana. Los numerosos embarazos y partos de su mujer obligaron al erudito a consultar con frecuencia temas delicados. Así, después del nacimiento de la primogénita, tuvo que preguntar la forma de curar unas heridas en los pezones y una hinchazón que no había curado el médico rural (29-XI-1743). También consultó a Piquer el remedio para superar la frecuencia de abortos y la respuesta del célebre médico no deja de ser curiosa: "para remediar estos daños conviene purgar blandamente a esta señora, y esto ha de hacerse luego que se halle en cinta, y ha de repetirse la purga cada mes hasta que haya cumplido los cuatro; en cuyo término muy raras veces se sigue el aborto; y para fortalecer la madre conven- 
drá aplicar a los lomos el emplasto que remitimos, el cual ciertamente es muy a propósito para precaver abortos" (21-XI-1746).

No puedo seguir la decripción de muchos casos, ni soy técnico para diagnosticar el acierto o error en las recetas. Pero Mayans consultó todo lo que necesitaba para la salud de su familia: problemas en la regla mensual de sus hijas, indigestiones y lombrices en los niños, tumores, hinchazones o clavos en los pies, constipados, fluxiones a los ojos, tratamiento de los dientes, enfriamientos otoñales y, sobre todo, la tuberculosis de su hija María Gregoria, que murió en 1765. Muchas veces sus amigos pidieron mayores precisiones antes de recetar. En otras, dictaminaron sin problemas: pildoras, jarabes, ungentos, aunque no faltan indicaciones para que prepare medicinas caseras que puedan remediar las enfermedades. Valga un ejemplo de Piquer para curar "unas calenturas ardientes espúreas con malignidad". Después de indicarle la génesis de la enfermedad, la necesidad de un vomitivo, alguna sangría si lo requirían las circunstancias, habría que darle unas bebidas y unos emplastos. Pero al llegar al séptimo día un cocimiento de yerbas hepáticas que se haría de la manera siguiente: "raíz de grama, de fresas y de chicorias, de cada una una onza; de pimpinela y endivia de acequia, un manojito; de las cuatro semillas frías mayores, de cada una, una dragma; de la flor de ninfea, un puñadito. Hágase el decocimiento según arte, hasta dos libras de remanencia para cuatro veces"(9-III-1754). Para ejemplo de receta del gran Piquer, basta.

Esas eran las consultas a los grandes médicos en momentos difíciles y que no sabían curar los médicos locales, o de los que el enfermo no se fiaba. Ahora bien ¿quién podía consultar a estos personajes? El caso de Mayans era único y la mayoría de los olivenses tenía que contentarse con los médicos locales, aunque tuvieran semejantes enfermedades. Más todavía, ¿dónde encontrar los medicamentos? Porque los boticarios no parecen existir, dado que en repetidas ocasiones el mismo Mayans recurre a Andrés Ferrando, boticario de Valencia, pese a la censura de sus amigos médicos. Unas palabras indican las dificultades para conseguuir las medicinas ordenadas: "y faltando aquí los mejores medicamentos, sin haberlos en todos estos contornos, ni tiempo para despachar por ellos a esa ciudad, ni para consultar a $\mathrm{Vm}$. por la gravedad y actividad de tantos males..." ( M. a Seguer, 9-VIII-1755)

Desde esa perspectiva, se explica el uso frecuentísimo de una medicina más casera y tradicional. Como en esa misma carta a Seguer, indicaba el erudito que ante la aparición de un "málísimo tumor debajo de la barba ( a un hijo) que, según la curación regular se ha procurado madurar con malvines", pero ante la lentitud del proceso, hubo que abrir el tumor "y aplicar el bálsamo del Dr. Millera, que hace maravillas". Claro que en estas últimas circunstancias estaba ya presente el Dr. Gros, un discípulo de Seguer que visitó al erudito.

Eso explica la serie de consejos caseros para resolver las enfermedades habituales: "ese catarro en parte es de destilación, y debe Vm. curarle, levantándose tarde y acostándose temprano y tomando agua caliente" (Juan A. a Gregorio, 20-V-1775) Y unas palabras que pueden constituir un paradigma de la medicina casera entre personas cultas, como era el canónigo Mayans, en los consejos sanitarios que dedica a su sobrina: 
"Voy a escribir menudamente como a médico. -Teresa no debe usar del agrio y zumo de limón porque es dañoso al pecho. -El agrio de limón cuaja, el agrio de vinagre disuelve. -No se han encontrado verdolagas a vender. -Que continúe con las hojas de la ninfea, acompañadas de la verbena. - Y si no, un emplasto de agrelles en lugar de verdolagas. En la hinchazón de los pies, nada, nada se pondrá. Ni usarse de baños porque hacen atracción. -No puede dejar de introducirse humedad en el cuerpo y es malo. -La tisanita que se componga de escorzonera, de pimpinela, raíces de chicorias y doradilla, que es lo más especial para la hinchazón de las piernas, y tiene buen gusto, que es lo que busca Teresa. -No conviene sangrarse por ningún caso, es aumentar el mal. -Sólo la bayeta caliente es bueno para los pies. -Esta hinchazón no pasará del tobillo. -Es bueno que beba y duerma. Tal vez entrará alguna accesioncilla. -Que continúe con la sustancia del pan" (17-II-1784).

Ese tipo de medicación no era exclusivo de Oliva, como puede suponerse, y debía constituir el modelo más frecuente en el sistema sanitario. Aludiré a dos hechos muy expresivos. Es conocida la amistad de Mayans con el Secretario de Gracia y Justicia, Manuel de Roda, y la correspondencia mantenida hasta el último momento permite algunas confidencias. Así el erudito supo que el ministro sufría de hinchazón en los pies y se apresuró a darle su receta: "el remedio ha sido beber a todo uso agua herbida con raíces de chicorias, la cual no tiene sino el inconveniente que excita mucho la orina. En lo demás es eficacísima para quitarle la hinchazón" (17-(II)-1778). En la misma línea, y en repetidas ocasiones, expone a su íntimo Martínez Pingarrón el uso del caldo de arroz hervido para resolver problemas intestinales. Estamos ante un sistema de recuperar la salud y curar las enfermedades por medios tradicionales, y aun en el caso de los médicos, muy anclados en la naturaleza. No en vano la cátedra de yerbas y el estudio de la botánica constituían pilares básicos de los estudios de medicina de la época.

\section{Vestidos y diversiones}

Hablar del vestido habitual de los olivenses del XVIII probablemente carezca de especial interés. Era el vestido habitual en la zona y de manera más concreta de las zonas agrarias valencianas. Pero sí puedo indicar algunos matices curiosos que no aparecen con frecuencia en nuestras historias.

La descripción que hizo Mayans de los tejidos fabricados en Oliva y del sistema de intercambios, dentro de su baja calidad (aunque mejor que los empleados para vestir a los soldados), permite suponer que se utilizaran para los vestidos más bastos, especialmente para las tareas agrícolas. En la villa había dos días de mercado semanales. Un día, delante de la casa del futuro Almirante Gabriel Ciscar, hoy plaza Rinconada de Alonso, que en julio de $17 € 7$ fue trasladado a la plaza de la Iglesia. El segundo, tenía lugar "el viernes en esta (plaza) de la villa". Se trataba de un mercado de productos agrarios, pero también permitía adquirir telas y otros productos elaborados que traían los comerciantes ambulantes. Las telas así adquiridas eran después cosidas en casa y adaptadas a las necesidades familiares. En múltiples ocasiones pueden leerse en las 
cartas cruzadas entre las hijas y la mujer de Mayans referencias a la compra de telas para confeccionar vestidos.

Ahora bien, no todos los productos relativos al atuendo personal podían adquirirse en Oliva. Especialmente las familias adineradas aprovechaban cualquier ocasión para adquirir vestidos, telas o zapatos, preferentemente en Valencia. El mismo Andrés Siscar solicitará a su tío don Gregorio el envío de "bayeta" para confeccionar una "mantellina" (5-XII-1768). En este sentido, una serie de datos, relativos a las compras de vestidos por parte de las familias más pudientes, contribuyen a clarificar los diferentes modos de vestir entre los grupos sociales. Mientras los campesinos vestían con prendas cosidas en casa y hasta con zapatillas de esparto o cáñamo, quienes disponían de medios económicos compraban zapatos franceses, medias y casacas y hasta sombrero de tres picos, según el decreto de Aranda después del motín de Esquilache.

Así nos lo demuestran unas listas, autógrafas de Mayans, solicitando unos productos, de los que escojo los más significativos: sortija de diamantes (30 L.), brazaletes (75 L., 5 s.) sombrero fino, peluca, casaca y dos pares de calzones, chupa de ropa de guardapiés, medias de color de la casaca, medias negras, hebillas con galón apuntillado y plumas, cintas correspondientes al guardapiés, zapatos a la francesa pero descansados, guardapiés de color de nácar o de perla, casaca a la española del mismo color que la colilla y guardapiés, basquiña de damasco sin sesgo, delantal a la medida, manillas de diamantes y de perlas, manto con puntas como se usa, guantes según el uso...(Fondo Alegre). En algún caso, el erudito recurrirá a sus amigos de Madrid, como el bibliotecario real Martínez Pingarrón, para que compre algunos botones especiales para sus hijas o alguna tela de importación para su mujer.

En esta línea, quisiera señalar unas anécdotas que permiten acercarnos a la realidad. En 1791, contrajo matrimonio un miembro de la familia Mayans, aunque no he podido averiguar con exactitud de quién se trataba. Las noticias vienen dadas por José Borrás, el procurador de las tierras de la familia, que residía en Oliva. Los novios llegaron al anochecer a la villa y fueron recibidos con mucha fiesta por don Pedro Siscar (el padre del futuro Almirante don Gabriel) y, "como había mucho concurso de gente popular, deseosos de ver la novia, fue preciso contentarles con dejarse ver con vestido de camino, que les causó mucha novedad el ver a una señora con apariencia de hombre por la parte exterior" (15-IX-1791). Pasaron después a la casa de la calle Mayor pero, cuando al día siguiente fueron al convento, "a visitar a la hermana monja con el mismo vestido de camino, bengala y sombrerito, con admiración y novedad de la gente rústica que se pensaban sería peregrina, y como no está puesta a ver semejantes vestimentas, cualesquiera de ellas les causa mucha novedad, habiéndolo sido también la del peinado, plumaje y demás andarajas con que se compuso el domingo..."

El contraste con el vestido habitual de los olivenses resulta evidente y muy comprensible la sorpresa generalizada. Y quizás al canónigo Mayans también le chocara un tanto toda la anécdota, pues manifestó cierta curiosidad por conocer las andanzas de la pareja de novios. Ante semejante insinuación, el procurador se despachó con una descripción de las ropas, vestidos y joyas de la novia, de los que hizo una exposición en 
las habitaciones de la casa: “... empezando primero por las galas del día de la novia, con sus batas de diferentes primores con las que se regalaron por diferentes parientes y bienhechores, todas guarnecidas con mucho primor y según la moda corriente. Seguía después un guardarropa y encima una escribanía de plata que se le regaló al novio, dos candeleros de plata, cuatro escudillas, obra de China y diferentes flores artificiales de mucho primor. Seguíase después diferentes vestidos ricamente guarnecidos de mucho primor, así de chalecos de camino y otras muchas piezas de valor. A la parte opuesta había ropas de cotonina muy fina y otras telas curiosamente labradas, muchas docenas de pares de medias aún vírgenes, muchos abanicos de moda y otros primores. Seguía después una mesa muy curiosa, para diversión de naipes y de ajedrez y encima dos candeleros de plata y otras cosillas. Seguíase después todo género de buenería (sic) de mucho valor de relojes, hebillas, zapatos bordados, sortijas de mucho primor, collares y otras muchas cosas de oro y plata, con lo que se remataba todo el círculo de aquella pieza, con admiración y pasmo de todos los que entraban a verlo, no siendo de menor admiración las curiosas y delicadas pinturas hechas de la propia mano de Ia Sra. novia. En este encantillo o encanto había mucho que ver y no faltó sujeto que arrojadamente lo estimó todo en 3.000 Libras" (19-XI-1791).

La plasticidad de la descripción, tan viva y sugerente, compensa con creces la extensión del texto. Vestidos a la moda, de gala y de viaje, telas finas y labradas, zapatos bordados, sortijas, collares... Era, en el fondo, un encanto para los campesinos. Uno empieza a entender algún que otro capítulo de las Visitas Pastorales relativos a las modas. Porque, en la visita de 1775 a la parroquia de Santa María, en el capítulo 12, pueden leerse las siguientes palabras: "Para precaver los pecados que puedan dimanar de la indecencia con que andan las mujeres por las plazas y calles en enaguas blancas, sin medias, vistiendo cortas, o descubriendo los pechos, les mandamos (bajo) pena de excomunión mayor..., eviten tan diabólicos estilos y exhortamos a la justicia secular cele sobre ello". Desconozco si se trata de una indicación generalizada a otros pueblos (en Oliva aparece en alguna otra Visita) pero no deja de sorprender la alusión a la existencia de minifaldas o escotes tan pronunciados.

Más frecuente es la alusión en las Visitas Pastorales al vestido talar de los clérigos, y precisamente la reiterada frecuencia con que se repite la prohibición demuestra que no se cumplía. Transcribo las palabras del capítulo 14 de la misma Visita de 1775: "y si bien las circunstancias y los tiempos para comodidad permiten, sin lesión de la decencia y respeto, andar de corto, mas no usar camisola, seda, capas, ni cabriolés de color, que asemejan o con dificultad distingan a las personas eclesiásticas de las seculares". Lejos todavía del "aggiornamento" del Vaticano II, la insistencia en la prohibición parece demostrar una cierta secularización en los hábitos talares, al menos en las salidas al campo, aunque el mayor rigor se aplica a evitar el lujo.

Pero volvamos a nuestra pareja de novios. Porque el procurador de los Mayans indicaba que, para festejar el acontecimiento, celebraron "un solemne refresco; para él han convidado al reverendo clero y a todas las principales personas: no dudo será suntuosa esta función". Con estas palabras nos introduce en el campo de las fiestas y diversiones. 
No voy a aludir a las fiestas tradicionales -Navidad (ya se daban las "estrenas" o regalos), Pascua, celebración de los santos Patronos- el número de días no laborables era excesivo a juicio de los reformistas. Dentro de sus posibilidades, las bodas constituían una ocasión para fiestas. Ese fue el caso del matrimonio de la hija de Francisco Mompó, uno de los agentes del conde de Oliva en el Ayuntamiento. Al "gran convite" asistieron, entre otros, el gobernador del señor en Gandía, el alcalde mayor, don Pedro Siscar (1769).

Pero había otras expansiones menos fastuosas, aunque más frecuentes. He aquí un testimonio del canónigo Mayans durante el viaje anual a Oliva en el mes de septiembre: "Francisco, Rosa y la calle mayor por entero os saludan. En nuestra calle y casa, cuando vamos, lo pasamos muy bien con frescor, vecindados y alegría... Tengo ganas de beber un vasito de orchata en compañía vuestra" (12-IX-1774). Da la impresión de de que las calles constituían un factor de unidad y sus moradores aprovechaban la fiesta de los santos titulares para tomarse un día de sosiego, holganza y diversión. Eso al menos se deduce de unas palabras de Andrés Siscar, por esas fechas alcalde ordinario de la villa:

"Yo quisiera quitar uno (abuso) de esta villa, que se ha introducido y aún mucho mayor en este año, que son las muchísimas fiestas de las calles en que se gasta muchísimo, arruinando las principales de la villa y arrabal, que son las de voto, sin que se supiese de pronto fuese yo el autor, pues van a porfía la gente rústica, gastando lo que no pueden, perdiendo muchísima hacienda que dejan de trabajar por ellas. Su Santidad ha permitido el trabajo en muchísimos días de fiesta por permisión, y estos cerriles van introduciendo muchos abusos dignos del mayor remedio, pues que hiciesen su misa y sermón, pase; pero tantos gastos en panes benditos, tortas, convites, cohetes y otros muchísimos gastos extraordinarios, sin contar la hacienda que pierden, es cosa lamentable, por lo que suplico a $\mathrm{Vm}$. vea de qué modo yo puedo gobernar para de esta forma remediar un abuso tan grave" (24-IX-1769).

El texto constituye, a mi juicio, un síntoma de la situación socio-cultural de muchos pueblos y, en general, de la España del XVIII. El contraste entre un alcalde que sigue y participa de los proyectos ilustrados. Porque Andrés Siscar no sólo conocía la bula de Benedicto XIV, en que disminuía las fiestas religiosas en que se prohibía el trabajo, sino que participaba de las ideas del equipo reformista. Precisamente al Presidente del Consejo dirigirá sus pasos para atajar el excesivo número de fiestas.

Resulta claro que los ilustrados participaban de semejantes criterios y su insinuación fue bien acogida por Mayans y también por Aranda. El erudito le indicó los trámites a seguir, como se deduce por la carta del alcalde quien, dentro de sus criterios restrictivos, desea "que las fiestas de los santos de la Piedra y san Roque (titular de la parroquia del arrabal) se continúen con satisfacción y la de san Vicente Ferrer, que sólo es un día, por ser patrón del reino", pero las demás, bastaría, en todo caso, con la misa y sermón, desapareciendo todo lo demás "con los panes benditos y tortas, que es un abuso" (1-X-1769). En efecto, los trámites fueron llevados al Consejo y, transcurrido un año, el 5 de noviembre de 1770, indica don Andrés que había llegado la orden de 
Aranda solicitando una relación del número de fiestas que se celebran en el pueblo, gastos, superfluidades, con la indicación de cuáles debían permitirse y cuáles suprimirse.

Claro que don Andrés podía permitirse, para él o para su familia, otras diversiones que no estaban al alcance de todos los vecinos. Así podía enviar a su mujer e hijas durante tres días a Pego (3-IX-1769), o que marcharan a Fuente Encarroz "a divertirse" en el sentido de la época, es decir, a distraerse. Más explícito es todavía el 3 de febrero de 1770. "Me están esperando para ir a Potríes al Porrat las chicas". Se trata de las fiestas de san Blas que, si bien se celebraba en Oliva con un mercadillo de chucherías y dulces, adquirió en Potríes tal relieve que atraía a los habitantes de la Safor.

Como puede observarse, muchas fiestas unían el carácter lúdico al religioso. En cambio, otras eran típicamente profanas y las numerosas noticias que proporciona Andrés Siscar resultan clarificadoras. Al parecer, en Oliva, no había corridas de toros. Eso al menos se deduce de sus palabras: "Mañana voy a acompañar a las chicas a Gandía a ver los toros y volveremos el martes con ellas, pues nunca han visto, y el primo Dn. Luis quiere que vayan, y es preciso acompañarlas" (29-VII-1769). En cambio, sí había representación de comedias. Algunas veces la función teatral tenía lugar en el espléndido palacio de los condes, aunque parece que la asistencia era restringida. Siscar, que en ese momento era teniente de alcalde mayor, sentía no poder asistir por sus ocupaciones (12-V-1770). Más popular parece era la representación de otras comedias: "Están previniendo los tablados para las comedias en esta plaza para las fiestas de los Santos de la Piedra" (28-VIII-1770). Otras veces, las comedias se representaban en Gandía y don Andrés aprovechó la circunstancia "que vine para ver una comedia", para realizar unas gestiones. Es una pena que en ningún caso nos diga el título, autor o carácter de la comedia. Pero el hecho de que en apenas cinco meses, puedan verse tres comedias, demuestra una actividad teatral nada despreciable.

Antes de finalizar este apartado, quisiera referirme al tabaco y a la caza, como medios de evasión y, en muchos casos, de diversión. Empecemos por el tabaco. Agustín de Ordeñana, en nombre del marqués de la Ensenada, quiso obsequiar a don Gregorio con vinos y tabaco. Mayans declinó el obsequio alegando que era filósofo antediluviano $\mathrm{y}$, en consecuencia, era abstemio. "Ni tampoco tomo tabaco como aquellas primeras gentes". Así, habiéndole regalado la duquesa de Gandía una caja con algunas libras de tabaco, lo repartió entre los frailes, que quizás no se acordarán de rezar por él. "No es razón exponer el tabaco de V.S. a la ingratitud de tales narices, ni menos que yo dé las gracias a V.S. con provocados estornudos, cuando he menester la mente muy despejada" (6-I-1753)

Esas palabras demuestran la frecuecnia, hasta entre los franciscanos, del uso del rapé. También Martínez Pinga rón tomaba rapé, como se deduce de la correspondencia con nuestro erudito. Y el mismo hijo de Mayans, aunque parece que evolucionó hacia otras formas de fumar después de su regreso de Madrid a finales de 1766. Más todavía, si don Gregorio no fumaba, en su círculo había fumadores. Así se deduce de la frecuencia con que aparece la solicitud de tabaco entre la lista de objetos a comprar. 
Ahora bien, en la lectura de correspondencia de olivenses de la época he visto dos datos, que paso a referir, y que demuestran la difusión del uso del tabaco. El primero es de 1768 y está relacionado con la enseñanza. Expulsados los jesuitas, la enseñanza de la gramática constituía una obsesión y muchos padres tenían miedo a enviar a sus hijos lejos de casa. Y no lejos, en "Gandía está perdido, pues los que han puesto para la enseñanza de la Gramática son (según me han informado) muy ignorantes y, lo que es que en lugar de darles egemplo en excusar vicios, sacan el cigarro en el aula y fuman" (24-IV-1768).

Todavía no existía el Ministerio de Educación y Ciencia que prohibiera fumar en las aulas, ni organismo internacional (político o de la salud) que dictaminara los inconvenientes de fumar en público, pero hería la sensibilidad de nuestros ilustrados. Y junto a los profesores que encendían su "cigarro" en clase, los labriegos que fumaban hasta en las eras. Baste recordar la descripción ya citada del incendio de las gavillas de trigo, hecha por el procurador de los Mayans, con la pertinente indicación: "y esto se debe todo a los señores fumadores, pues se encontró un pedazo de soga que tenían de prevención" (25-VI-1791). No deja de sorprender la continuidad de las tradiciones: la soga ha sido -y en determinados ámbitos continua siendo- el encendedor de los cigarrillos de los campesinos.

Ahora bien, si frecuente era la costumbre de fumar, no menos extendida estaba el uso de la escopeta para la caza. La correspondencia de Mayans con Martínez Pingarrón se centra en temas literarios y bibliográficos, pero, dada la familiaridad existente, aparecen con frecuencia alusiones a costumbres y hábitos de diversión. El hijo del erudito, Miguel, además de fumar, tenía fuerte atracción por la caza y el bibliotecario real le enviaba los aderezos necesarios. En ese sentido tenemos un texto confirmatorio del mismo Mayans que narra el viaje de su hijo, acompañado de Vicente Torá, primogénito del conde de Albalat, a Oliva en agosto de 1769, para cazar codornices. La práctica venatoria arrancaba de Denia y siguiendo el curso de los montes cercanos, llevaba al término de Oliva en tiempo que había terminado la veda. Esa cacería viene confirmada por Andrés Siscar: "Miguel llegó anoche ya tarde en compañía de Dn. Vicente Torá; ahora hay poca caza, y menos de codornices, pues en este año (ha) habido muy pocas y el tiempo es muy pesado para ir a cazar" (27-VIII-1769).

El mismo don Andrés era un buen aficionado como demuestra la insistencia con que recurre al erudito para que le arreglen el fusil en Valencia, aunque en la cuenta no aparece especificada la razón de los gastos: "Estoy muy contento de lo bien trabajado que viene" (26-III-1769). Y en otro momento cuenta una gamberrada con su comentario: "Yo lo sé porque fui a cazar a la dehesa y me lo contaron todo".

Claro que tan frecuente uso de la escopeta propiciaba las ocasiones para cometer alguna gamberrada, aunque fuera promovida por personas mayores y de cierta relevancia social. Así a principios de enero de 1769 , un grupo de amigos, que estaban de holganza, se acercaron a una choza de la playa, "gritando rinde cristiano, y tirando escopetazos". Los dos moradores huyeron campo a través, llegaron al monte siempre perseguidos y volvieron a huir hacia Denia. El susto fue mayúsculo y uno de ellos, Fe- 
lipe Miramón, tuvo que ser sangrado y con calentura. Hubo sus discusiones y el comentario de Andrés no deja de ser expresivo: "Hubo un empeño de palabras fuerte con el Dr. Luis, pero se sosegó y después fue el fraile de Sancho (dos de los participantes en la gamberrada) y dijo que no se había de saber, pero es público ya en ésta. Si otros lo hubieran hecho, qué hubiera sucedido" (9-I-1769).

¿Borrachos? Pocos datos he podido encontrar sobre la práctica o frecuencia de bebidas hasta la borrachera. Apenas he hallado una alusión, aunque muy significativa. Ciertamente en Oliva se producía gran cantidad de vino. Y la Visita Pastoral de 1744, en su artículo 14, prohibe se confiese durante la Nochebuena, porque acuden muchos borrachos. Ello hace sospechar que podría ser bastante más frecuente la práctica de bebidas alcohólicas.

¿Bailes? No hay duda de que los olivenses bailaban. Pero no deja de constituir un matiz curioso: Ios hijas de Mayans tuvieron que aprender a bailar para asistir a las fiestas después de su traslado de residencia a la capital del Turia. Al menos, los bailes eran distintos, y las jóvenes hijas del erudito tuvieron que imponerse nuevas costumbres lúdicas para introducirse en la vida social de Valencia (Teresa Mayans a su madre, 26XI-1767)

\section{Vida social. Un municipio manipulado}

Pese a la riqueza agrícola y el evidente período expansivo, podemos vislumbrar algunos hechos curiosos que demuestran la complejidad de la vida en una villa valenciana del Antiguo Régimen. Algunos olivenses, quizás por razones económicas, se veían obligados a emigrar. Unas veces obligados por las autoridades: traslado de trigo de Alicante a Madrid en 1765 por el decreto de libertad de granos dictado por Campomanes. Eran obligados a trasladarse, junto con sus caballerías, en condiciones nada favorables a sus intereses económicos. "Aquí se continúa la conducción del trigo a Madrid. Es increíble el daño que causa esto a la agricultura y a los labradores, alcanzando a todos. Es un segundo equivalente hasta ahora, y para muchos, cuyas bestias perecen, peor" (Mayans a Asensio Sales, 7-I-1765). Estas palabras fueron matizadas al correo siguiente, al especificar que los transportistas iban obligados, y a los vecinos se les obligaba a contribuir económicamente: "Aquí se repiten las órdenes para la conducción del trigo sin exención, y a los que nos competa nos cuesta dinero para que vayan otros voluntariamente, y bien pagados. Yo aún temo que a lo último se repartirá el trigo para que apeste a los que le coman" (14-I-1765). Estas palabras concuerdan con las noticias facilitadas por Pingarrón desde Madrid anunciando la mala calidad del cereal transportado.

Otras veces los vecinos enigraban por decisión propia al interior o fuera de España. Al interior, tenemos el caso de la colonización de Sierra Morena. Será de nuevo Mayans quien nos comunique el hecho de los vecinos que buscan acomodo en el proyecto propiciado por el equipo reformista y dirigido por Olavide. Pero el erudito no tardará en comunicar que los olivenses volvieron pronto a su casa y hogar, con la con- 
vicción de que estaban mejor atendidos en su villa natal. Sólo un caso he encontrado de un vecino de Oliva que emigra a América, que se halla presente en las batallas de la guerra de la independencia de las Trece Colonias de Norteamérica respecto a Inglaterra. La carta se halla escrita desde Nueva Orleans con la sorpresa del nuevo mundo por sus dimensiones y el sistema de vida tan sorprendente en la colonia (s.f. Fondo Familia Alegre).

Más triste es sin duda la suerte de los marginados en el interior de la misma villa, como son los gitanos. No poseo muchos testimonios, pero sí poseo los datos proporcionados por Mayans en una carta a Blas Jover. El Fiscal de la Cámara del Consejo de Castilla comunicó las ideas de los rigurosos decretos del marqués de la Ensenada sobre los gitanos, y el comentario de Mayans es luminoso. Cuando observó el movimiento del ejército pensó que se trataba de prender a los gitanos, "y cuando los vi presos, me causó suma dificultad su destino". En efecto, ni las Indias, ni los presidios del Mediterráneo, ni las islas (que se convertirían en nido de piratas), ni las fronteras. Teme que el remedio sea peor que el mal, porque por donde han pasado "han hecho a los campos más mal que la langosta". Y no resulta fácil la solución. "Domiciarlos será corromper los lugares de su domicilio. Restituirles los bienes es imposible. No restituirles el residuo de ellos es inhumanidad y hacerlos más ladrones". Y frente a las teorías casuistas, Mayans parece inclinarse por la aplicación de la justicia: los gitanos como todos los ciudadanos, con la aplicación de la justicia, como a todos. "Si quien hace el delito paga la pena merecida, brevemente no habrá gitanos". Ahora bien, a juzgar por sus palabras, podemos deducir que por esas fechas se introdujeron gitanos en Oliva: "V.S. haga cuanto pueda para que cuanto antes se tome la providencia que parezca menos dañosa, porque la tardanza es muy perjudicial a las poblaciones a donde nos ha venido esta plaga, peor que las egipcíacas, aunque tiene su nombre" (27-IX-1749). Estos datos parecen demostrar que en el siglo XVIII se introdujeron los gitanos en Oliva. Así parecen confirmarlo las noticias que da Pons Moncho de que, según las fuentes documentales de san Roque, en 1694 aparece por primera vez la alusión a una gitana que contrajo matrimonio con un payo, y en 1780 tuvo lugar la boda de una pareja de gitanos.

Pero interesa mucho para entender la vida de una villa ver el funcionamiento de las instituciones con proyección social: el municipio y la iglesia.

Los ayuntamientos valencianos, es bien sabido, sufrieron la adaptación al modelo castellano después de la Guerra de Sucesión y la aplicación de la Nueva Planta. Pero en ningún caso desaparecieron los derechos señoriales. El poder civil en Oliva quedó estructurado de la siguiente manera. Gobernador o alcalde mayor, representante del señor, en cuyo palacio residía, con amplios poderes jurisdiccionales. Era nombrado directamente por el conde (Borja o Benavente). Había, además, un alcalde ordinario, cuatro regidores, un síndico y un secretario, nombrados anualmente por el señor a propuesta de una terna y con la proclamación y firma del gobernador del Consejo de Castilla. Teóricamente no podían desempeñar cargos municipales durante dos años seguidos, pero en la práctica siempre había forma de burlar la ley, colocar a los familiares o cambiar de cargo. Lo cierto es que las oligarquías locales poseían una fuerza inmensa 
y, en el fondo, eran apoyadas por el señor que disponía de fieles y sumisos colaboradores.

No creo necesario insistir en el hecho de que el conde -unido a los Borja del ducado de Gandía hasta 1748 y después, ambos, a los Pimentel, condes de Benavente- residía en la corte y su intervención en los nombramientos estaba mediatizada por sus secretarios que apoyaban a sus clientes. El equipo entrante nombraba, asimismo, una serie de personas para cargos de gran importancia en la vida ciudadana como los alguaciles o cequieros, cargo especialmente importante para el buen funcionamiento del sistema de riegos. Y, por supuesto, había un abogado municipal y sus agentes en Valencia y en Madrid.

El primer aspecto que sobresale por su acusado relieve es el inmenso poder del señor. Poder jurisdiccional por medio del gobernador, influjo decisivo en el nombramiento de los cargos municipales, poder en la vida eclesiástica puesto que la parroquia de santa María era de patronato laical y el conde decidía sobre la persona del párroco y de diez beneficiados, ventajas económicas tanto en la propiedad del ingenio o molino de azúcar como en la suculenta participación en los diezmos. No puede extrañar, por tanto, que el conde tuviera siempre fieles servidores en el ayuntamiento que buscaban favorecer los intereses del señor, a cambio de su favor y protección.

El mejor instrumento en manos del señor era, sin duda, el gobernador o alcalde mayor. Nombrado por el conde, era su representante, vivía en su palacio, ejercía sus atribuciones jurisdiccionales. Miradas las cosas desde nuestra perspectiva, resultan lógicas las divergencias entre el gobernador del condado y el alcalde ordinario que también gozaba de atribuciones judiciales y legalmente era el justicia. Aunque ambos recibían su autoridad del señor, no sorprende que el gobernador quisiera disminuir el poder del alcalde ordinario con una acusada tendencia a mirarlo como autoridad suya delegada. Se trataba de un matiz jurídico muy importante, que un jurista como Mayans recordó sin tapujos: "Y ha de suponer V.Ex. que el alcalde de esta villa siempre ha tenido jurisdicción, en más de cinco siglos absoluta y privativa; desde el año 18 acá cumulativa y preventiva con el gobernador, el cual preside; pero no tiene jurisdicción sobre el alcalde. Y éste, hallándose ausente el gobernador, como lo estaba, mandó librar un testimonio sobre hecho sucedido en la casa capitular dentro de las 24 horas. De donde ha resultado que el alcalde justa y debidamente ha apelado a la Audiencia. Y certísimamente tendrá sentencia en favor. Lo que conviene es que V.Ex. no se dé por entendido, porque la alcaldía y la gobernación son empleos que da V.Ex. dependientes de su voluntad, y no tratándose de disminuir la jurisdicción, que por costumbre va obteniendo el gobernador, ni poniéndose en controversia, debe querer V.Ex. que el alcalde mantenga la suya procediendo de derecho" (Mayans a Benavente, 8-XI-1755). Será cuestión de constantes divergencias, como demuestra Andrés Siscar al contar la intromisión del alcalde mayor en la jurisdicción del alcalde ordinario, aun después de la aparición del síndico personero (11-IV-1768).

La autonomía del alcalde ordinario era muy importante. En el fondo, las censuras más generalizadas se dirigirán contra el gobernador, indolente y contemplativo unas 
veces; despreocupado, agresivo y desvergonzado en otras y, en muchos casos, con evidente abuso de autoridad judicial. Este último aspecto será motivo de la censura de Mayans: "Cuando Terol ha de dar alguna sentencia, explora cuánto le da cada una de las partes, y haciéndolo saber a entrambos, va pujando hasta el término que le parece... Finge delaciones y supone autos para estafar. Las penas ordinarias de dos y tres libras las agrava a quince, veinte o más $y$, poniendo terror, cobra lo que puede sacar de los desvalidos" (8-XI-1755). Terol era un gobernador que había residido durante 38 días en casa del erudito de quien recibió valiosos consejos, pero después desvió su conducta en aspectos de moralidad pública, hasta de acosos sexuales a las mujeres del condado, además de los abusos judiciales indicados.

En otros casos, las censuras tienen mayor alcance, pues se dirigen contra la figura del gobernador como representante del señor: los gastos que importa, el autoritarismo de que hace gala, el servilismo ante los intereses del conde o el desprecio de cuanto pueda favorecer al común. En el fondo, se trasluce el deseo de que todos los cargos municipales sean elegidos por los vecinos y, como consecuencia, la desaparición del representante del señor. He aquí las palabras de Andrés Siscar: "Aquí estos días pasados ha corrido una novela que, si fuera cierta, no hay duda que sería de los mayores beneficios que se pudiesen conseguir, pero me persuado que el contrario grande, fuerte, como son todos los señores, la tengo por fábula; y es que quitaban todos los alcaldes mayores de los señores y que sólo quedaban los alcaldes ordinarios pues, a más de quitarnos un sobrehueso a quien hemos de dar a comer, vestir y calzar y algunos chavos más, se podrían disputar algunos (de)rechos que en el día son imposibles, quitar todo género de protección a los enemigos de la patria. Pero yo lo tengo, como he dicho, por novela y fábula, porque es cosa muy buena" (22-V-1768).

No se olvide la fecha, posterior al establecimiento de los diputados y síndico personero, cuyos efectos podremos observar. Ahora interesa resaltar dos aspectos en las palabras de don Andrés: gastos y poder del representante del señor pero, sobre todo, su conexión con los oligarcas de la villa. Ni que decir tiene que ambos aspectos están íntimamente relacionados.

Como es bien sabido, el equivalente constituyó la regulación de los impuestos fiscales establecida en la Nueva Planta. La obligatoriedad de su percepción no significó que todos los contribuyentes pagaran de manera uniforme sus aportaciones. Y ello porque la distribución tributaria dependía de quienes ocupaban los cargos municipales. En este sentido tenemos un caso clarísimo en el sistema empleado en Oliva.

En septiembre de 1746, Mayans escribía al Intendente (marqués de Malaespina) una carta en que narraba las arbitrariedades del ayuntamiento de Oliva en el reparto del equivalente. Después de recordar que, según los reales decretos, a nadie podía cobrársele más del $14 \%$ y el $12 \%$ del rédito de los censos, demuestra que a él le gravan con más del 24\%. Para demostrar sus afirmaciones presenta un certificado del municipio con la enumeración de sus fincas y las rentas de cada una. El Intendente reconoce el derecho del erudito, con el matiz de que el "vecino hacendado, que por sí cultivare sus propias tierras y beneficiare sus frutos, se ha considerado por regla imponerle un 12 
por ciento de su patrimonio y 4 por ciento de consumos, que es todo un 16 por ciento, y lo más a que se ha extendido el arbitrio y ha podido cargar" (Escritos económicos, pag. 278). Esta norma fue comunicada a los ediles olivenses señalando la irregularidad de su proceder. El ayuntamiento reconoció que los terratenientes forasteros pagaban el $11 \%$ y los vecinos el $22,5 \%$ pero Mayans el $24,25 \%$. Lo curioso del caso es que, pese al decreto del Intendente, los regidores no cambiaron el criterio impositivo. El erudito se dirigió entonces a instancias superiores (el Secretario de Estado), pero la denuncia no evitó los abusos del grupo que controlaba el municipio. Esta actitud sólo tiene una explicación: "pero lo que ahora sucede es que los alcaldes y regidores se proponen unos a otros y se toman las cuentas mutuamente, la duquesa aprueba estas elecciones porque permiten que mantenga las sisas contra la orden del rey, no la obligan a pagar el equivalente, practican lo mismo con sus arrendadores y con el gobernador. Los regidores, por su propia autoridad, se rebajan la novena parte, siendo hombres plebeyos, se hacen exentos de muchas cargas, imponen mayores tributos, ocultan muchos bienes suyos, tasan bajamente otros, otros muy altamente $y$, finalmente, prueban todo lo que quieren porque tienen libros y contralibros y notarios falsarios; y, en suma, aparejo y ánimo para cualquier maldad. De donde nace que ningún particular se atreve a emprenderlos porque gastan del común y tienen el abrigo de la duquesa..."( 17-IX-1746).

Difícilmente puede expresarse con mayor claridad las conexiones existentes entre el señor y los caciques del pueblo. Y es que ocupar el cargo de alcalde o de regidor no constituía sólo un cargo honorífico. Entrañaba, además, un instrumento de poder y un medio frecuente de enriquecimiento. Además del reparto del equivalente, alcalde, regidores y síndico administraban los bienes propios y arbitrios del común, disponían la solicitud de créditos o la devolución de censos, establecían la fecha y el precio de los productos agrarios (seda, trigo, maíz...), permitían u obstaculizaban la actividad de los comerciantes, pagaban al maestro de primeras letras o nombraban al profesor de gramática latina.

Su poder era, por tanto, grande. Basta analizar el sistema de venta de la seda, ya aludido en páginas anteriores. Alcalde y regidores disponían la fecha para vender la seda y el precio a pagar por los comerciantes. Estos ofrecían un precio que los representantes municipales podían aceptar o rechazar. En este sentido, retrasaban las fechas a su voluntad. Pero la necesidad y urgencia de los cosecheros de vender el producto, para poder pagar el arrendamiento de las tierras o el vencimiento de los censos, que vencía por san Juan, propiciaban una serie de negocios no siempre limpios: podían comprar directa o indirectamente a los cosecheros más necesitados de dinero la seda, que después vendían más cara, o percibían las gratificaciones de los comerciantes "paniaguados".

Todo ello explica el interés de formar parte del equipo de gobierno municipal y el poder de la oligarquía local, los "caciques" como los llama Mayans, los "enemigos del común" en terminología de Andrés Siscar, con el consentimiento y complacencia del señor. Quizás ningún ejemplo más claro como el interés del franciscano P. Llorca, natural de Oliva, que, después de alcanzar altos grados en la orden, logró introducir a dos sobrinos suyos en el grupo de los regidores. Y tantas intrigas desarrolló que asustados 
los olivenses, utilizaron a Mayans para que escribiera a sus amigos de la corte, y hasta el nuncio de su Santidad en Madrid, para que paralizaran las intrigas del P. Llorca. Esto explica que, en determinadas ocasiones, las tensiones fueran muy fuertes hasta llegar, en un caso, a sacar el espadín en sesión del consejo municipal.

Mayans utilizó un argumento sólo relativamente válido: la necesidad de abogados hábiles para defender el pleito del agua frente a las pretensiones de los pueblos vecinos. Pero tampoco los que dirigían el pleito del agua, como el abogado Francisco Mompó, a quien apoyaba en esos momentos el erudito, abandonaban fácilmente el cargo. El mismo Mompó, aunque no podía continuar dos años seguidos en cargos municipales, controló de hecho el municipio durante más de dos décadas, y cualquier razón era buena para conseguir una excepción. Valga, como ejemplo, la solicitud de Mayans, dirigida al Regente de la Audiencia, para que el alcalde ordinario fuera renovado en el cargo. Luis Salelles actuó de forma enérgica y resolvió una serie de problemas locales. "El latrocinio se había enseñoreado tanto de estos campos que nadie podía decir que era dueño de sus frutos; porque siendo el término dilatadísimo, las cosechas varias y en diferentes tiempos y los vecinos sin haberes algunos más de los que la tierra puede sostener, se le tenía por cosa imposible que la justicia pudiese velar en tantas partes". Pero el alcalde Salelles actuó con tanta energía dentro y fuera de la villa (campos, caminos...) que acabó con los ladrones. Además, había sabido vivir en armonía con el gobernador del conde y con los regidores, lo que le permitió realizar empresas muy importantes: un justiprecio de todos los bienes de los vecinos (hacía más de 14 años que no se llevaba a cabo) lo que ha permitido la redacción de un nuevo "libro padrón", el arreglo de los caminos y construcción de los puentes necesarios (27-IV-1761). El conde confirmó al alcalde Salelles en su cargo y las protestas de sus émulos fueron paralizadas por las gestiones del erudito ante el Regente a quien recordó las fechorías del recurrente.

Claro que a veces los latrocinios adquirían carácter de bandidismo organizado que abarcaba la zona montañosa del Valle de Gallinera. En ese caso, la autoridad del alcalde ordinario era insuficiente y precisaba la intervención de la Audiencia. Eso ocurría en 1758. Era Fiscal Juan Vega Canseco, y su amistad con Mayans nos permite conocer los proyectos del magistrado y el criterio del erudito. Vega Canseco decidió obligar a los municipios a establecer unas rondas para acabar con el bandidismo organizado. El erudito pensaba que era un decreto legal, pero dudaba de su eficacia. "Los bandidos se han hecho fuertes en la Valle de Gallinera. Allí no hay hombre poderoso que les pueda resistir, los lugares son cortos y desarmados. De aquí nace que los alcaldes no pueden hacerles frente. Cada particular tira a guardar su piel. Si alguno habla una palabra contra ellos, luego es amenazado de muerte. ¿Quién hablará, pues? Ellos son unos miserables tributarios que los aniquilan. Solamente, pues, los puede alejar una compañía de soldados, o dos, que sin gravar mucho los pueblos, tomen las entradas y salidas y los busquen. Esto de obligar las poblaciones a rondas que se den las manos, es un gravamen insoportable y absolutamente inútil. Y la experiencia lo confirma" (16-IX-1758). Y en repetidas ocasiones insistirá en que la obligación de las rondas es "un tributo gravosísimo" y nc comprende cómo hombres desarmados, padres de familia y cobardes, 
se enfrentarán a los bandidos. Se vislumbra, por parte de la administración, la solución dictaminada por el conde de Aranda en 1765, como Capitán General de Valencia, con el reparto de armas y apoyado por las autoridades municipales. Pese a la minuciosidad de las normas, el plan de Aranda ha sido calificado por Enrique Giménez, como "de escasa operatividad práctica". Otras veces el peligro venía del mar. Pues, aunque la presencia de piratas y argelinos había disminuido, en alguna ocasión aparece visible en la correspondencia mayansiana el temor de los olivenses que, por lo demás, tenían las torres de vigilancia en la playa.

De cualquier forma, el nombramiento de gobernador o de alcalde ordinario y regidores constituía muchas veces el resultado del equilibrio de fuerzas que gravitaba, desde fuera, sobre el gobierno municipal. He aquí unas palabras de don Gregorio al abogado de la villa (Luciano Sulroca) muy expresivas: "Estos estados de Gandía y Oliva absolutamente se gobiernan por D. Luis Clavijo, procurador general de la duquesa, antiguo criado de la casa y hechura de D. Ignacio Berdún; por D. Felix Pérez, gobernador de Gandía patrocinado de su tío D. Gaspar Cebrián, y por el Dr. Mompó, procurador de D. Isidro Gil de Jaz, que tiene suma autoridad en la casa" (31-XII-1764). Si tenemos en cuenta que Gil de Jaz era fiscal del Consejo de Guerra e íntimo del conde Aranda, y Cebrián Oídor de Valencia, comprenderemos muchas cosas, entre ellas, el poder de Mompó en el ayuntamiento que manipulaba con habilidad, basado en el favor del señor. Uno comprende bien que, en un momento de irritación -o de sinceridad- don Gregorio exclamara con lucidez: la ruina de los pueblos son los señores, los cabildos y los caciques. Era una crítica aguda y certera de las bases sociológicas del Antiguo Régimen.

Pese a que tales bases no cambiaron, los decretos dictados por Aranda después del motín de Esquilache sobre los diputados del común y síndico personero repercutieron en la vida administrativa de los pueblos españoles. También en villas pequeñas y en las de señorío. Respecto a Oliva, una serie de cartas de Andrés Siscar, junto con algunas apreciaciones de los hermanos Mayans, nos permiten conocer su desarrollo y funcionamiento. Andrés Siscar, sobrino de don Gregorio, constituye una figura sugestiva: medios económicos suficientes, enemigo de los jesuitas al tiempo que envía sus hijos al colegio de los escolapios de Valencia, regalista que pide el Juicio imparcial de Campomanes, está al corriente de los hechos y rumores, nacionales e internacionales. Partidario de las reformas introducidas por Aranda, sigue una evolución en los cargos administrativos que le permite alcanzar un profundo conocimiento: colector del equivalente (1767), alcalde ordinario (1769), teniente de alcalde mayor (1770). Dispuesto a poner orden e iniciar las reformas propiciadas por Aranda, sus confidencias semanales en carta a don Gregorio nos permiten una buena radiografía de las dificultades en la aplicación de las reformas.

En primer lugar, surge el problema de la aplicación del decreto sobre los diputados del común y síndico personero. En este caso será Juan Antonio quien exprese sus dudas. "El miércoles 15 se eligieron los diputados. No se eligió síndico personero porque este oficio, según el núm. 7 , sólo debe haberle donde el sindicato está enajenado en alguna familia o recae en un regidor. Pero aquí en Oliva al principio de siglo era de la 
elección de la villa y ahora está usurpado por los duques de Gandía, que nunca eligirán persona que vaya sobre sus intereses. En los pueblos circunvecinos han elegido síndicos personeros, tal vez por no entender la orden, tal vez por la razón de estar usurpados los sindicatos". Y Juan Antonio expone una duda, que entraña un indudable alcance político, sobre "si en Oliva debe haber síndico personero, o si el síndico procurador general debe volverse a la elección antigua", porque en el último caso, siendo a propuesta del ayuntamiento y con la aprobación del señor, nunca irá en contra de los intereses del conde. (J.A. Mayans a Gregorio, s.f.). Esa duda está en la base de la consulta al conde de Aranda. Porque, apenas llegada la carta de convocatoria de las elecciones, el cartero hizo el primer fraude: entregó la carta no al justicia, a quien iba dirigida, sino al cacique Mompó, que inmediatamente se puso en contacto con los representantes del señor para retrasar la elección. Fue don Gregorio, en carta presentada a nombre de Andrés Siscar, quien contaba estos hechos a Aranda y solicitaba las normas a seguir (11-III1767).

EI Consejo de Castilla decretó la elección de los diputados del común y del síndico personero. Y, por cierto que las elecciones despertaron pasiones y campañas de propaganda. Andrés Siscar, testigo directo, nos cuenta los hechos: "Ayer y hoy ha sido la votada de comisarios electores para diputados y personero; $y$ aunque han salido todos los de la pandilla de Mompó solicitando hasta el amanecer votos, me acaban de asegurar queda de parte de los favorecedores del común" (29-XI-1767). Y aunque no quería escribirle al conde de Aranda, le han convencido para que le cuente la evolución de los hechos. Porque, según don Andrés, ha "habido muchas quimeras y diligencias indecorosas sobre la elección de diputados y personero, que ya avisé a Vm., por parte de los enemigos del común, que han sido tales que no se pueden ponderar, pues a ofertas y dádivas y amenazas..." (6-XII-1767).

En ambos textos aparecen los oligarcas municipales calificados de "enemigos del común" y será la terminología habitual en la correspondencia. El contraste establecido con los elegidos por el pueblo resulta evidente y no sólo en las palabras. Pronto empezaron a notarse los efectos: se revisaron las cuentas de propios y arbitrios con multas a los implicados, se mejoró el reparto del equivalente y el cobro se ejecutó con formalidad y limpieza. Valgan como testimonio de la situación las siguientes palabras: "en fin, no se dejará ninguna cosa que no se siga hasta lograr el bienestar del común y poner un arreglo formal de todo, pues todo se seguirá hasta el fin. Ha habido y hay muchas cosas que no se pueden decir sino a boca" (18-VIII-1767). Especial interés adquieren las finanzas, pues por lo que "se ha visto, lo practicado y resultante del auto, en que se ve el mayor desarreglo, monipodio y malversación de los caudales del común". No creo sea necesario recordar que este grupo, que deseaba sanear la administración municipal, encontró siempre el apoyo del conde de Aranda como Presidente del Consejo de Castilla.

La elección de los diputados del común y del síndico personero continuó, al menos durante unos años, celebrándose con la animación que producía la disparidad de criterios de los distintos grupos. Pero el nombramiento de Andrés Siscar como alcalde ordinario y después teniente de alcalde mayor le permitió actuar de manera decisiva en 
múltiples aspectos de la vida municipal. Sin afán de señalar todas las actividades, insinuaré algunos puntos de mayor relieve. Pero, antes de tan rápida enumeración, es menester aludir al cambio de mentalidad después de observar el resultado del sistema electivo. "Mucha cosa es lo que Vd. me dice que se resolverá (que) se acaben los regidores y únicamente permanezca el gobierno de los diputados y personeros. Pues digo que, si los comunes nombran diputados y personeros, no hay duda que siempre tirarán a nombrar los sujetos de mayor satisfacción y si permanece el alcalde había de ser propuesto por los mismos y electo por el rey para la libertad de los derechos de los pueblos de señorío, pero se habían de quitar los alcaldes mayores y alguaciles, que éstos buscan sus ampliamientos en los derechos (y) mantenerse a costas de sus vecinos o súbditos y lo demás que a Vd. no se le ignora". Al mismo tiempo alude a un rumor de que Felipe V había ordenado en 1707 "que en todos los pueblos de su reino hubiese un alcalde ordinario que ejerciese la jurisdicción real" (24-X-1768). Esta carta de Andrés Siscar a don Gregorio es uno de los testimonios más sorprendentes de las aspiraciones íntimas de los grupos reformistas.

Pero los problemas para un alcalde ilustrado eran muchos. En primer lugar, con las mismas autoridades superiores. Es bien sabido que la presencia del ejército constituía una plaga para el pueblo: hospedaje de la tropa (acuartelada y en el mesón) y de los mandos (en casas privadas), la paja para la caballería, abusos de la soldadesca... "Mucho siento venga tropa a ésta, porque nunca acarrea cosa buena" (29-V-1769). En el caso de la paja para la caballería había que luchar, además, contra los asentistas que, con apoyo del Intendente, pretendían recibir ventajas en el suministro para los caballos. La situación era compleja porque la cantidad exigida era grande, había que proporcionarla en el lugar indicado y a precio inferior. Algunos vecinos alegaron privilegio (caso de Mayans) pero muchos campesinos tuvieron que comprarla para ofrecerla a los militares. Ante esas circunstancias, Andrés Siscar se opuso y, con los reales decretos en la mano, exigió el pago de la paja de acuerdo a los precios reales. "En asunto de paja se tomarán todas las medidas con noticia de todos los reales decretos e instrucción de intendentes, que está en Librería de jueces, con otras noticias más con la orden del acuerdo dimanado del Consejo de 1766 en asunto a diputados y personero, en que los diputados deberán cuidar y velar que por los asentistas se pague a los vecinos sus justos precios, según las contratas hechas con su majestad" (24-VII-1769). El asunto fue alargándose y, cuando le obligaron a pagar la sal destinada para la villa -y no recibida, por no ser necesaria- pensó que se trataba de la venganza del Intendente por su actitud respecto a la paja.

Otro problema con el ejército era el sorteo de quintas, aunque en este asunto nada tuviera que ver el alcalde ordinario. Pero constituía un nubarrón muy temido por los vecinos. Los testimonios podrían multiplicarse. "Ayer se hizo aquí el sorteo para la quinta; se hizo segundo sorteo para reemplazo, y en tercer lugar del reemplazo salió Blas Girau, bachiller de teología" (2-VIII-1762). Las gestiones por ver de librarlo no fueron eficaces y su padre "salió de su aprieto con ciento y cincuenta pesos que le ha costado un sustituto, sin lo demás que no se dice" (23-VIII-1762). Constituía realmente una pesadilla y es un tema constante y reiterado en la correspondencia conservada. El 
sistema utilizado en Oliva aparece expuesto con claridad en carta de Mayans al obispo Asensio Sales: "Aquí en Oliva se ha hecho la quinta con gran prudencia y quietud. Pero ha costado mucho dinero a los pobres mozos que para que los quintados, que han sido diez, fuesen gratificados, dieron cada uno, quien diez pesos, quien menos, y después los quintados han tenido ese socorro, bien que para alguno no ha sido suficiente consuelo por ser hijos únicos y hacendados; y es cosa fuerte que tales no puedan suplir en su lugar alguno o algunos hombres de bien y robustos, que servirían mejor. El rey ciertamente remediaría muchos desórdenes, si los supiera" (2-II-1762). Mayans, además de indicar el número de los mozos, diez para una población de mil vecinos, y la ayuda económica de los otros mozos no quintados, nos señala su criterio negativo sobre el sistema. Salva la intención del rey, pero insinúa su juicio favorable a unos soldados mejor preparados y más o menos voluntarios.

No toda la actividad de las autoridades estaba ocupada por asuntos ajenos a la vi1la. Andrés Siscar se vio sumergido en problemas municipales. El eterno problema del agua, tanto respecto al abastecimiento del riego de los campos, como en la canalización de las inundaciones producidas por el río o rambla de Gallinera, cuyo proyecto presentó al conde. En el campo urbanístico sobresale el asunto del empedramiento de las calles. En principio encontró bastante resistencia y, sólo después de ver en la práctica los efectos positivos, fue aceptado por la población que acabó solicitando se aplicase a la mayoría de las calles. Cada vecino pagaría la parte correspondiente a su casa, para lo que el alcalde dio bando oficial, para evitar hoyos existentes y "malos empedrados" (26-III-1769).

Uno de los problemas que más preocupó a Andrés Siscar fue, sin duda, la enseñanza. El maestro de primeras letras cobraba una miseria y, con motivo de su muerte, propuso el aumento de salario. He aquí sus palabras que constituyen la expresión de su mentalidad. "Ayer murió el maestro Blas Tur y, según el auto del Consejo, debe darse por oposición, pero como el salario es tan corto, no habrá sujeto hábil que acuda a la pretensión. Yo soy de dictamen se haga diligencia de un sujeto hábil y de circunstancias para la educación de los niños, que es el primer pie para el adelantamiento, pues sin un salario bueno no podrá ser sujeto hábil" (27-IX-1770). El Consejo de Castilla permitió el aumento de 9 libras al salario, "que es nada para encontrarse maestro de habilidad", a juicio de don Andrés, que presionó para que se enviara segunda representación al Consejo (28-1I-1771).

No menos problemas produjo la creación de la escuela de Gramática. En un intento de elegir un buen maestro de latín (único requisito para acceder a los estudios universitarios) Mayans había fracasado en 1746 . Franciscanos, jesuitas, regidores y señor, se confabularon y nombraron a un franciscano que no debía ser un gran latinista, ni buen pedagogo, y la Escuela de Gramática dejó de ejercer su función de preparar a los estudiantes para el acceso a la Universidad. Por eso, Andrés Siscar quiso reactivar la enseñanza. Cuando expuso su deseo a Mayans, el erudito contestó que, según los proyectos iniciados, nada quedaría para maestro y necesidades docentes. Pero don Andrés lo tenía muy claro: una buena administración daba para todo. Por eso, el 24 de abril de 1768 exponía con crudeza la necesidad de la Escuela de Gramática. "Pero al presente 
lo que conmueve al común es el clamor de todos los padres que tienen hijos en la escuela y que estudiaban gramática, teniendo ésta muchos inclinados y deseosos de este beneficio, porque van disueltos los chicos. En Gandía un desorden, hasta fumar los maestros en las aulas; a Valencia, la mayoría de los padres, por ser pobres, no pueden enviarlos".

Son las circunstancias locales favorables a las gestiones realizadas por Mayans ante el Consejo de Castilla (Aranda y Campomanes) que dieron por fruto el establecimiento de la Escuela de Gramática en Oliva, como estudié en mi ponencia presentada en el Simposio con motivo del II Centenario de la muerte de Mayans. Ahora sólo quiero señalar la reacción de rechazo por parte de los oligarcas. En principio mandaron a sus hijos a estudiar a Vergel donde había un maestro con escasas luces. Después presionaron para crear dificultades al maestro, Juan Barberá, que había ganado la plaza por oposición pública, acabaron desterrando la Gramática mayansiana en 1774 y cerraron la escuela. Aunque se restableció la enseñanza por la Gramática de don Gregorio a finales de 1778 , el problema era más profundo que la animadversión personal a un paisano ilustre. Una carta de los alumnos de la Escuela, sin fecha, demuestra los grandes problemas sociales que subyacen. Corrijo la ortografía, pero dejo las palabras y los valencianismos que demuestran la ignorancia del castellano:

"Sr. D. Gregorio. El maestro de gramática se fue, porque Luis Veses le amenazó que posaría (pondría) en la presó (prisión) y que le perdería, porque su hijo le agarró al maestro de las orejas y a brazo partido riñó con el maestro. Y és(te) se defendió y le dio algunos azotes. El chico se lo dijo a su padre y éste, lleno de cólera, le dijo al maestro mil picardías y le amenazó que posaría (pondría) en la presó (prisión) y que le perdería y por esto andó (anduvo). Y no es mentira. Los estudiantes".

Triste panorama de la enseñanza en las villas medianas en el Siglo de las Luces. En esta rapidísima enumeración de datos y problemas relacionados con la vida municipal, hay un hecho que no quiero pasar por alto. En el tradicional viaje de septiembre a Oliva, el canónigo Mayans escribe: "Esta tarde habrá en esta villa Consejo general, en la plaza mayor, con licencia del acuerdo y asistencia de la justicia; cosa no vista después de la entrada de las leyes de Castilla. El asunto son los procedimientos de Canemás (recolector de los diezmos). Yo me alegro de haber estado en Oliva, cuando el cabildo ha resuelto esta guerra. Esto se escribe domingo por la mañana" (19-IX-1774). Me limito a señalar las dos facetas: evocación de los fueros abolidos por la Nueva Planta y un anticipo de las protestas antiseñoriales simbolizadas por los diezmos.

\section{El poderoso influjo eclesiástico}

Decir que la vida cotidianc de Oliva en el siglo XVIII sería incomprensible sin las manifestaciones religiosas constituye una verdad tan conocida como evidente: las fiestas del año litúrgico (Navidad o Pascua), las celebraciones de los Santos Patronos, las cofradías y procesiones, las misiones periódicas, los sermones en cualquier acto festivo..., forman parte de la vida de la población. Como en todas las pequeñas ciudades de 
la época. Que se trata de una religiosidad tridentina -o mejor dicho, postridentina- contodos los caracteres típicos de predominio clerical y con una fuerte impronta exterior, no hay la menor duda: control del cumplimiento pascual, visitas pastorales con indicación de los abusos que debían corregirse, frecuentes excomuniones por retraso en el pago de los diezmos. Quizás en este caso, al tener el contrapunto de un ilustrado como Mayans que, dentro de su sincero catolicismo, expresa su repulsa a las formas barrocas de la religiosidad, podemos establecer un evidente contraste. Por eso, dentro de los caracteres generales de la religiosidad popular de la época, señalaré con la máxima brevedad algunos rasgos específicos de la villa.

En Oliva existían dos parroquias: santa María, parroquia de la villa, y san Roque enclavada en el arrabal o antigua morería. Había, además, un convento de francisanos (Nuestra Señora del Pino) y un convento de monjas clarisas. La expansión demográfica y económica secular se hizo visible también en el campo de las construcciones eclesiásticas. La villa, con gran esfuerzo y la ayuda económica del arzobispado y del señor, construyó la inmensa mole arquitectónica de santa María. Las obras duraron casi todo el siglo y los arquitectos se vieron obligados a superar un pronunciado desnivel que provocó la caída de la cúpula. Muchos de los problemas en la construcción del templo, con las intrigas, presiones, diferencias entre los grupos de vecinos son visibles en la correspondencia conservada por Mayans. También los párrocos de san Roque iniciaron una reforma arquitectónica que sólo alcanzó a la capilla del Cristo, pues el obispado no permitió la construcción de todo el templo, mientras no finalizase el de la villa. Más aún, a lo largo del siglo se construyeron dos ermitas: una en la calle de San Vicente (simple altar cubierto para celebrar en la calle el culto al santo) y otra más ambiciosa dedicada a los santos Antonio Abad y Antonio de Padua. Finalmente, las monjas clarisas edificaron una sala lujosa para recepción de visitantes, con limosnas del arzobispo, aunque con quejas de algunos vecinos que creían deberse a influjo de los franciscanos.

Esta estructura eclesiástica, similar a muchos pueblos y villas del antiguo Reino de Valencia con morería, adquiría un matiz curioso. En 1549, el conde de Oliva consiguió, por bula de Pablo III, la creación de un patronato laical sobre la parroquia de la villa: el señor dotaba las rentas para el párroco (con el título de plebán) y 10 beneficios. Dado que el plebán y beneficiados debían ser vecinos y, por derecho de patronato, su nombramiento dependía del conde, el poder del señor -ya grande en el terreno civil- aumentaba enormemente al controlar al mismo tiempo los cargos eclesiásticos. Si a esto añadimos el hecho de que algunos religiosos y bastantes monjas eran naturales de Oliva, podemos comprender fácilmente que el clero olivense se viera implicado en todos los grandes problemas ciudadanos. En más de un momento, se dio el caso de que el alcalde ordinario fuera familiar muy próximo del cura plebán. Y en ambos casos, el nombramiento dependía del señor. No creo necesario decir que en esas circunstancias la plebanía siempre estaba ocupada por un clérigo perteneciente a las familias más poderosas.

Dentro de la más estricta lógica, las manifestaciones externas de religiosidad eran muy numerosas. Quizás las más aparatosas tuvieran lugar con motivo de sequías $(1708,1756)$, excesivas lluvias, mucho más frecuentes $(1744,1763,1783)$, por escapar 
de un terremoto (1748) o por múltiples plagas (1774). En esas circunstancias, una procesión con las imágenes de los Santos Patronos, con oraciones, plegarias y sermones, recorría la villa.

De menos brillo exterior, pero quizás más expresivas, la serie de manifestaciones de religiosidad popular. Valgan como testimonio, además de las fiestas de las calles cuya frecuencia vimos censuradas por Andrés Siscar, unas palabras de Juan Antonio en uno de sus viajes a Oliva, en carta a sus sobrinos: "Ayer fue la fiesta del rosario en casa. Si hubieras estado (Francisco) aquí, me hubieras excusado la fatiga de llevar el pendón" (8-II-1773). Si a esto unimos la frecuencia con que pasaban las imágenes religiosas de una casa a otra, podemos hacernos una idea aproximada de semejantes prácticas devotas. Que era práctica frecuente podemos deducirlo de unas palabras de Mayans al conde de Aranda: "De vestir las imágenes y enviarlas a las casas se siguen grandes y superfluos gastos" (14-X-1769). Claro que en algún caso, encontramos una clara discrepancia. Un católico ilustrado, como don Gregorio, se opone a que entre en su casa la imagen de la Divina Pastora, por considerarla herética (sólo hay un Pastor, Cristo) y la Virgen es persona humana. Y no contento con ello, escribe al Presidente del Consejo de Castilla contra la procesión en honor de semejante imagen.

Casi todas estas ceremonias (excepto la de la Divina Pastora, que se debía a influjo de los capuchinos) estaban propiciadas por las cofradías, entre las que tenía especial relieve la del Rosario que, orientada por los dominicos, había logrado enorme difusión desde la segunda mitad del XVII. Lo curioso del caso -valdría la pena confirmarlo en otros pueblos- es que las familias adineradas y con poder político controlan las grandes cofradías. Y, en algún momento, se ven comprometidos en la rendición de cuentas, exigida en las Visitas Pastorales. Porque con excesiva frecuencia los visitadores exigen el pago de atrasos en las cofradías, pero también en la administración de beneficios. Hasta el extremo de amenazar en 1724 al alcalde y regidores si en el espacio de 4 meses no rendían las cuentas de la administración del Hospital y de la Cofradía de Nuestra Señora.

Todo ello, dentro de la reforma postridentina, legislada en la diócesis valenciana por los sínodos de los arzobispos Urbina y Rocaberti en pleno siglo XVII: control de las misas pro populo, residencia de los clérigos, conferencias semanales de formación (teología y moral), hábito talar con la especificación de que no basta el cuello (con la precisión de 10 libras de multa al transgresor), explicación del catecismo... son algunos de los mandatos más frecuentes en las Visitas Pastorales.

Es menester confesar, sin embargo, que el control alcanza también a los fieles. Como era tradicional, la ficha de cumplimiento pascual, con amenaza de excomunión por retraso en presentar el aval. Pero hay otros mandatos más expresivos. Ya aludimos a la visita de 1775 en que se solicitaba la ayuda del poder civil, si fuera preciso, para impedir que las mujeres mostı aran grandes escotes o faldas cortas. Y no fue la única vez. O la indicación de que tuviesen cuidado en separar la cama de los niños respecto a la de los padres. Aunque, sin lugar a dudas, el mandato más veces repetido a lo largo del siglo es que los novios no visiten a sus prometidas en sus casas. Son mandatos que constituyen la mejor expresión de la moral religioso-social de la época. 
Queda un aspecto al que deseo aludir: las excomuniones. Entre los Quinque libri, ocupa el último lugar el de los excomulgados, después de bautizos, confirmaciones, matrimonios y defunciones. Pero puede comprenderse que la excomunión en las parroquias de Oliva no adquiere nunca carácter doctrinal y ni siquiera inquisitorial. El caso más frecuente es el de "malmessor": 6 casos en 1727, 2 en 1728... Es la tónica general. Algún caso por falta de cumplimiento pascual o amenaza al justicia de la villa y a su teniente por no devolver un mulo a su propietario clérigo, o simplemente por no pagar el diezmo.

Porque las deficiencias en cumplir con los diezmos y primicias debieron ser frecuentes. Unas palabras de Juan Antonio nos muestran un mundo confuso: "Canemás está muy odiado con razón. La tierra siempre ha estado notada de mal pagadora de diezmos, y con razón; pero él hace cosas nuevas... Creo que hace cuenta de continuar el arrendamiento del diezmo. Dará mucho en qué entender. El lo niega" (12-IX-1774). El arrendador del diezmo había sufrido ya alguna multa por irregularidades en la venta del producto y, pocos días después, tuvo lugar el Consejo general en la villa para tratar de "los procedimientos de Canemás" (19-IX-1774).

Las parroquias arrendaban los diezmos y su cobro corría por cuenta del arrendador. Por suerte tenemos un informe de 1758 , en que el párroco señala el sistema de contribución. Diezmaban trigo, maíz, algarrobas, uva, legumbres, habas, lino, cáñamo, azúcar, higos, aceite y simiente de gusanos. Ahora bien, no todos los productos contribuían en idéntica proporción. Trigo, maíz y legumbres pagaban uno de cada diez y, si se trataba de "tierra ochena", de lo que "queda, saca el señor de ocho uno". (Para la primicia se contribuía con 1 por cada 35). De algarrobas y uva para vino, los cosecheros dejaban dos montones en el campo: uno mayor para el diezmo (del que tomaba el señor el diezmo tercio) y otro menor para la primicia. En cuanto al aceite se refiere, el informe es muy explícito: pagan 1 de cada cuatro, y en esta contribución están incluidos todos los impuestos, y la distribución entre los perceptores aparece claramente precisada: de 9 barchillas, 2 son para el molino, 4 para el señor, 2 para el diezmo y 1 para la primicia. De la simiente de gusanos, los cosecheros aportaban un real por cada onza, que se distribuía: 1 sueldo para el diezmo, 6 dineros para la primicia y otros 6 dineros para el señor. Finalmente, el paner (hortalizas, huvas de mesa y hierba alfalfa) así como el carnaje (carneros y lana) contribuían 1 de cada 8 y en esa cantidad se incluía el diezmo, la primicia y los derechos señoriales.

Quizás haya sorprendido la suculenta percepción que de los tradicionales diezmos y primicias percibía el señor. Y la cantidad era muy elevada. No poseo una relación pormenorizada del alcance de los diezmos. Pero, a juzgar, por el arrendamiento de las primicias (como hemos visto, mucho menor) debió constituir una saneada fuente de ingresos. Porque la parroquia de santa María, gracias a la bula de la plebanía, recibía las primicias de Oliva, Fuente Encarroz, Potríes, Rafelcofer, Alquería de la Condesa, Alcudiola y Beniflá. Ahora bien, el arrendamiento de las rentas primaciales alcanzaba una suma muy elevada, como indican las correpondientes a tres que escojo como símbolo: 958 L. 2 s. 10 d. (1724); 1.520 L. (1757); 3.390 L. (1799). 
Se trata de un aspecto material que poco contribuye a clarificar las corrientes de espiritualidad. Pero los aspectos exteriores son más fáciles de controlar que los interiores, más sutiles y no fácilmente cuantificables. En ese sentido, sólo conocemos con claridad la actitud de los hermanos Mayans que en libros y en la correspondencia manifestaron sus criterios, en gran parte discrepantes con la religiosidad oficial. Menos claro, pero también bastante explícito, el pensamiento del alcalde reformista Andrés Siscar: regalista, enemigo de los jesuitas, sin grandes profundidades teológicas. Y en esa línea habrá que incluir a ciertos personajes más preparados culturalmente. Bastaría recordar a su primo Pedro Siscar (el padre del Almirante don Gabriel), que también envió a estudiar a sus hijos al colegio de los escolapios de Valencia. De ese grupo saldrían años después los primeros liberales.

En contraste, la masa del pueblo sigue con docilidad las directrices del clero. No procede una descripción minuciosa de la altura intelectual o de su actitud religiosa. Algunos son abiertos a las nuevas corrientes: Juan Bautista Hermán (sobrino del párroco de san Roque e íntimo de Mayans) que recibió el influjo del erudito, íntimó con Campomanes en Madrid, consiguió el favor de Aranda pero, siendo canónigo de Valencia, fue perseguido por el arzobispo Fabián y Fuero. Más conservadores fueron otros clérigos. Aunque es menester recordar que los frecuentes sermones permitían conocer, siempre que tuvieran capacidad, diferentes matices espirituales. Cerca estaba Gandía, con su Universidad dirigida por los jesuitas, que propiciaba la presencia de predicadores en las festividades, como Gener, uno de los buenos escritores de teología histórica. Aunque a decir verdad, el mayor influjo se debió a los franciscanos, por los conventos de frailes y monjas, en los que ingresaban muchos olivenses.

Estamos ante una visión de la vida cotidiana en la villa de Oliva en el siglo XVIII. Influida, en gran parte, por las fuentes de que he podido disponer. Lamento no haber tenido a mi alcance el archivo municipal. Sólo la enorme cantidad de cartas de vecinos, algunas de personajes vinculados al Ayuntamiento, me han permitido llegar al conocimiento de algunos aspectos importantes. De cualquier forma, son datos que nos permiten acercarnos a la forma de vida de los habitantes de una villa media bajo el régimen señorial. 